ORNL/ER-296

LOCKUEED MATTIN

ENVIRONMENTAL

RESTORATION

PROGRAM

\section{PECEIVED}

FFB 121997

OSTI

\title{
Environmental Restoration Plan for the Transfer of Surplus Facilities to the Facility Transition Program at Oak Ridge National Laboratory
}


Energy Systems Environmental Restoration Program

ORNL Environmental Restoration Program

Environmental Restoration Plan

for the Transfer of Surplus Facilities

to the Facility Transition Program

at Oak Ridge National Laboratory

Date Issued-August 1995

Prepared by

Science Applications International Corporation

Oak Ridge, Tennessee

Prepared for

U.S. Department of Energy

Office of Environmental Management

under budget and reporting code EW 20

Environmental Restoration and Waste Management Programs

Oak Ridge National Laboratory

Oak Ridge, Tennessee 37831-6285

managed by

LOCKHEED MARTIN ENERGY SYSTEMS, INC.

for the

U.S. DEPARTMENT OF ENERGY

under contract DE-AC05-84OR21400 


\section{Science Applications International Corporation}

contributed to the preparation of this document and should not be considered an eligible contractor for its review.

This report has been reproduced directly from the best available copy.

Available to DOE and DOE contractors from the Office of Scientific and Technical Information, P.O. Box 62, Oak Ridge. TN 37831; prices available from 615-576-8401 (fax 615-576-2865).

Available to the public from the National Technical Information Service, U.S. Department of Commerce, 5285 Port Royal Rd., Springfield, VA 22161. 


\section{DISCLAIMER}

This report was prepared as an account of work sponsored by an agency of the United States Government. Neither the United States Government nor any agency thereof, nor any of their employees, makes any warranty, express or implied, or assumes any legal liability or responsibility for the accuracy, completeness, or usefulness of any information, apparatus, product, or process disclosed, or represents that its use would not infringe privately owned rights. Reference herein to any specific commercial product, process, or service by trade name, trademark, manufacturer, or otherwise does not necessarily constitute or imply its endorsement, recommendation, or favoring by the United States Government or any agency thereof. The views and opinions of authors expressed herein do not necessarily state or reflect those of the United States Government or any agency thereof. 


\section{CONTENTS}

ABBREVIATIONS $\ldots \ldots \ldots \ldots \ldots \ldots \ldots \ldots \ldots \ldots \ldots \ldots \ldots$ vii

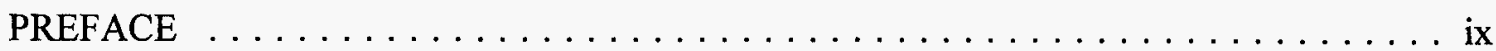

EXECUTIVE SUMMARY $\ldots \ldots \ldots \ldots \ldots \ldots \ldots \ldots \ldots \ldots \ldots \ldots \ldots \ldots \ldots \ldots$

1. INTRODUCTION $\ldots \ldots \ldots \ldots \ldots \ldots \ldots \ldots \ldots \ldots \ldots \ldots \ldots \ldots \ldots \ldots$

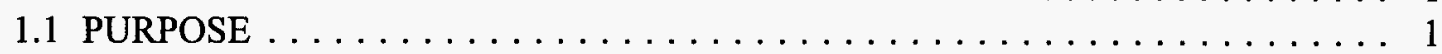

1.2 BACKGROUND $\ldots \ldots \ldots \ldots \ldots \ldots \ldots \ldots \ldots \ldots \ldots \ldots \ldots \ldots \ldots \ldots \ldots \ldots \ldots \ldots$

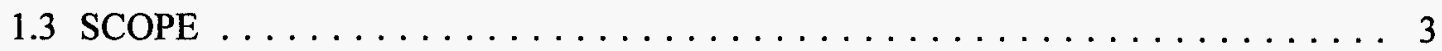

1.4 ROLES AND RESPONSIBILITIES $\ldots \ldots \ldots \ldots \ldots \ldots \ldots \ldots \ldots \ldots \ldots \ldots \ldots \ldots \ldots$

1.4.1 ORNL ER Program Manager $\ldots \ldots \ldots \ldots \ldots \ldots \ldots \ldots \ldots \ldots \ldots \ldots$

1.4.2 ORNL ER Facility Program Manager $\ldots \ldots \ldots \ldots \ldots \ldots \ldots \ldots \ldots$

1.4.3 Transition Working Group $\ldots \ldots \ldots \ldots \ldots \ldots \ldots \ldots \ldots \ldots \ldots \ldots \ldots$

2. FACILITY TRANSITION PROCESS $\ldots \ldots \ldots \ldots \ldots \ldots \ldots \ldots \ldots \ldots$

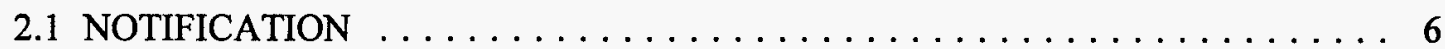

2.2 RESOURCE IDENTIFICATION $\ldots \ldots \ldots \ldots \ldots \ldots \ldots \ldots \ldots \ldots$

2.3 TRANSFER OF RESPONSIBILITY $\ldots \ldots \ldots \ldots \ldots \ldots \ldots \ldots \ldots \ldots, \mathbf{8}$

2.4 FACILITY DEACTIVATION $\ldots \ldots \ldots \ldots \ldots \ldots \ldots \ldots \ldots \ldots \ldots$

2.5 SURVEILLANCE AND MAINTENANCE $\ldots \ldots \ldots \ldots \ldots \ldots \ldots \ldots \ldots$

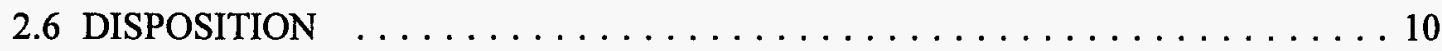

3. FACILITY TURNOVER AND ACCEPTANCE BY EM-40 $\ldots \ldots \ldots \ldots \ldots 12$

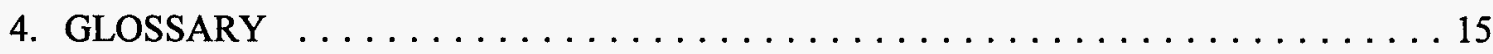

Appendix A: Secretary of Energy Memorandum $\ldots \ldots \ldots \ldots \ldots \ldots \ldots \ldots$ A-1

Appendix B: Surplus Facility Inventory Assessment Project Checklist ......... B-1

Appendix C: Surface Building/Structure Identification and Grouping Flowchart $\ldots \ldots$ C-1

Figure 1. ORNL ER Transition Program organization and implementation $\ldots \ldots \ldots 2$

Table 1. Schedules transition facilities $\ldots \ldots \ldots \ldots \ldots \ldots \ldots \ldots \ldots \ldots \ldots$ 


\section{ABBREVIATIONS}

$\begin{array}{ll}\text { ADS } & \text { Activity Data Sheet } \\ \text { CAP } & \text { Cost Account Plan } \\ \text { CERCLA } & \text { Comprehensive Environmental Response, Compensation, and Liability Act } \\ \text { D\&D } & \text { decontamination and decommissioning } \\ \text { DOE } & \text { Department of Energy } \\ \text { DP } & \text { Office of Defense Programs } \\ \text { EM } & \text { DOE Office of Environmental Restoration and Waste Management } \\ \text { EM-1 } & \text { Assistant Secretary for the Office of Environmental Restoration and Waste } \\ & \text { Management } \\ \text { EM-40 } & \text { Office of Environmental Restoration } \\ \text { EM-60 } & \text { Office of Facility Transition and Management } \\ \text { ER } & \text { environmental restoration } \\ \text { ES\&H } & \text { environmental safety and health } \\ \text { FTE } & \text { full-time equivalent } \\ \text { FY } & \text { fiscal year } \\ \text { HSE } & \text { health, safety, and environmental } \\ \text { MOA } & \text { Memorandum of Agreement } \\ \text { NEPA } & \text { National Environmental Policy Act } \\ \text { ORNL } & \text { Oak Ridge National Laboratory } \\ \text { OSR } & \text { Operational Safety Report } \\ \text { RCRA } & \text { Resource Conservation and Recovery Act } \\ \text { S\&M } & \text { surveillance and maintenance } \\ \text { SFIA } & \text { Surplus Facility Inventory and Assessment } \\ \text { TSR } & \text { Technical Safety Requirement } \\ \text { TWG } & \text { Transition Working Group } \\ & \end{array}$




\section{PREFACE}

This document is being written in response to the Federal Facility Agreement (FFA) signed by the U.S. Department of Energy, the U.S. Environmental Protection Agency, and the Tennessee Department of Environment and Conservation in November 1991. The FFA was required by the Superfund Amendments and Reauthorization portion of the Comprehensive Enivironmental Response, Compensation, and Liability Act for all federal facilities placed on the remediation of the liquid low-level waste system tanks that have been removed from service at Oak Ridge National Laboratory, Oak Ridge, Tennessee. 


\section{EXECUTIVE SUMMARY}

This report will provide guidance on management, coordination, and integration of plans to transition facilities to the Facility Transition Program and activities as related to the Oak Ridge National Laboratory (ORNL) Environmental Restoration Program facilities. This report gives (1) guidance on the steps necessary for identifying ORNL surplus facilities, (2) interfaces of Surveillance and Maintenance (S\&M) and Isotope Facility Deactivation program managers, (3) roles and responsibilities of the facility managers, and (4) initial S\&M requirements upon acceptance into the Facility Transition Program. 


\section{INTRODUCTION}

\subsection{PURPOSE}

The purpose of this document is to provide guidance on management, coordination, and integration of plans to transition facilities to the Facility Transition Program and activities as related to the Oak Ridge National Laboratory (ORNL) Environmental Restoration (ER) Program facilities. This document provides guidance on the steps necessary for identifying ORNL surplus facilities, interfaces of Surveillance and Maintenance (S\&M) and Isotope Facility Deactivation Program Managers, roles and responsibilities of the facility managers, and initial S\&M requirements upon acceptance into the Facility Transition Program.

Implementation of the Surplus Facility Inventory and Assessment (SFIA) project will anticipate transfer landlord responsibilities from the Office of Defense Programs (DP) to the Department of Energy (DOE) Office of Environmental Restoration and Waste Management (EM). As shown in Fig. 1, management of this implementation plan is the responsibility of the ORNL ER Program Manager and the ORNL ER Facility Program Manager. A team of technical staff will be formed to compose a Transition Working Group (TWG) that will provide (1) management support and liaison interface between functional organizations; (2) technical support for managing, planning, organizing, scheduling, and implementing subtask activities; (3) assessments to identify compliance issues and perform health and safety risk analysis; (4) cost estimating, scheduling, budgeting, funding, and full-time equivalent (FTE) requirements in addition to provisions for S\&M and ancillary activities; (5) database management and integration; and (6) conduct of operations and regulatory compliance support.

\subsection{BACKGROUND}

The SFIA project was initiated by Secretary of Energy, Hazel R. O'Leary, in 1993 to identify DOE facilities and assets, assess hazardous and/or radiological contamination that pose a liability to DOE, and to develop a defensible process for managing and dispositioning these facilities (see Appendix A: Hazel R. O'Leary to Thomas Grumbly, Surplus Facility Inventory and Assessment Project, Memorandum to Heads of Departmental Elements, October 4, 1993). The major objectives of the SFIA were to define the number and condition of process-contaminated surplus assets and those ancillary assets that have been in direct support of the processcontaminated asset. The first step in this project was to develop an accurate inventory of contaminated surplus facilities and to categorize facilities into one of five groups (Groups I-V). Those facilities categorized in Groups I-III, which are either currently surplus facilities or are planned to be surplus facilities over the next 5 years, were included in Phase II. In Phase II, additional information was obtained to (1) assess and/or characterize the physical condition and contamination of Group I-III facilities; (2) rank the facilities for transfer to EM using a threatbased ranking system; and (3) develop cost estimates for managing those high ranking facilities expected to transfer to EM in FY 1996. Phase II assessments involved a physical walk down and completion of a 22-page checklist for approximately 100 facilities at ORNL, risk-ranking surplus facilities in terms of potential environmental, safety, and health (ES\&H) risk using the Surplus Facility Threat-Based Priority Model matrix. As a result of this ranking, facilities were grouped 
ORNL ER Program Manager

$\downarrow$

ORNL ER Facility Program Manager

$\downarrow$

Orphan Surplus Facilities

Transition Working Group

Working Group Subproject Levels

$\begin{array}{cccc}\text { SFIA } & \text { Conduct } & \text { Database } & \text { D\&D } \\ \text { Transition } & \text { of } & \text { Integration } & \text { Facilities } \\ \text { Facilities } & \text { Operations } & & \text { Integration }\end{array}$

Orphan

Surplus

Facilities

Assessment
Risk

Assessment/

Regulatory

Compliance

Fig. 1. ORNL ER Transition Program organization and implementation. 
in a high-, medium-, or low-risk ranking group as appropriate. Additionally, initial cost estimates for risk-ranked facilities were prepared in Phase III to develop estimated costs for anticipated S\&M, characterization, and corrective actions for immediate problems for those facilities scheduled to be transferred to EM. All information obtained during each phase of the SFIA was managed and maintained in the SFIA database.

\subsection{SCOPE}

The scope of this plan encompasses a description of programmatic considerations for management of activities related to the transition of surplus facilities from DP or other programs to EM. This plan provides guidance on organizational structure, basic roles, responsibilities, and interfaces for ORNL ER Facility Program Manager and ORNL facility managers, and it indicates major areas of implementation to ensure consistency among participants. This plan provides a format for the following:

- implementation of site-specific plans including S\&M activities necessary to reduce the potential ES\&H risk posed by facility contaminants and conditions, to ensure worker and public safety, and to protect the environment;

- S\&M planning, coordination, and oversight of all S\&M activities, deactivation/compliance actions to deactivate, assess, and characterize facilities to reduce existing ES\&H vulnerabilities and minimize required S\&M activities while protecting health and safety of personnel and the environment;

- program integration, management oversight, and interface with ORNL management; and

- inspections, characterization, ES\&H related issues, risk analysis, and regulatory issues needed to ensure safe transition.

\subsection{ROLES AND RESPONSIBILITIES}

This section defines the key Martin Marietta Energy Systems, Inc. (Energy Systems), interfaces and responsibilities for the management and transition of ORNL facilities. Careful planning, organizing, and coordination of transition activities are essential to ensure compliance with regulatory agencies and protection of health, safety, and environment (HSE).

\subsubsection{ORNL ER Program Manager}

The ER Program Manager is responsible for the overall management, implementation, and coordination of programmatic and policy issues. Additionally, the ER Program Manager interfaces with appropriate DOE and regulatory authorities.

\subsubsection{ORNL ER Facility Program Manager}

The ORNL ER Facility Program Manager is responsible for the overall management of orphan/surplus facilities and the implementation and integration of these facilities into a transition management program. This requires designated components of the organization to 
- review activities of orphan/surplus facilities and ensure compliance with DOE orders, federal regulations, and state and local requirements and regulations;

- implement engineering studies to identify compliance issues and perform health and safety risk analysis to minimize costs and health related concerns;

- interface directly with Transition project managers and the ES Program Manager to translate engineering estimates into Activity Data Sheets (ADSs), current-year work plans, and work authorization to facilitate identification of ER Program funding requirements;

- recommend actions/alternatives for facility maintenance, funding, and risk reduction;

- interface with ORNL ER Program functional managers and site managers to ensure that applicable ER Program requirements are integrated;

- communicate with project managers to develop cost account plans (CAPs) and monitor project activities; and

- provide information management systems to collect, compile, compute, and report ER facility related information.

Additionally, the ORNL ER Facility Program Manager (or designee) is responsible for transfer of orphan/surplus contaminated facilities into the ORNL ER Program (Transition Management). The ORNL ER Facility Program Manager is responsible for long-range planning, compliance assessments, risk analysis, development of transfer schedules and cost estimates, identifying policy issues, and coordinating ORNL ER Program activities with ORNL management and with ORNL organizations. The ORNL ER Facility Program Manager will perform the following actions:

- assess condition and potential risk of releases of contamination from orphan/surplus facilities and regulatory compliance issues;

- determine funding requirements;

- identify activities to reduce cost, risks, and noncompliances with regulatory issues;

- $\quad$ acquire funding for necessary actions;

- identify actions necessary for transition of facilities to Facility Transition Management Program; and

- identify schedule for transition of orphan/surplus facilities to a transition management program.

\subsubsection{Transition Working Group}

The TWG for the orphan/surplus facilities will address project integration, management, funding, and FTE requirements in addition to provisions for S\&M ancillary activities. Program integration and management includes program-level management, program oversight, budget preparation and cost accounting, and coordination of any and all activities related to facility 
preparation and continuing S\&M. Assess orphan/surplus facilities for regulatory noncompliance and risk analysis and reduction. Program integration activities include, but are not limited to, reviewing, editing, and approving weekly highlights, and monthly progress reports. This function also serves as a formal point of contact and program interface with ORNL management, Energy Systems Central Environmental Restoration and Waste Management, DOE, and its other prime contractors. The TWG will comprise support staff to provide (1) management support and liaison interface between functional organizations (e.g., D\&D, ER, etc.), (2) technical support for organizing, scheduling, and implementing subtask activities, (3) in-depth assessments to identify compliance issues and perform health and safety risk analysis, (4) cost estimating, scheduling, budgeting, funding, and FTE requirements in addition to provisions for S\&M and ancillary activities, (5) database management and integration, and (6) conduct of operations and regulatory compliance support. 


\section{FACILITY TRANSITION PROCESS}

The specific activities involved with facility transition include notification (by the DP facility manager to EM) requesting transfer of a surplus facility (or facilities), identification of work scope and budget/personnel resources to be transferred, transfer of the facility, facility deactivation, and establishment of S\&M plans to be used prior to final disposition. Table 1 provides a list of facilities currently scheduled for transition. Isotopes facilities which include approximately 19 facilities will be transitioned in FY 1995. In FY 1996 and 1997, 31 additional facilities are scheduled for transition. Facilities scheduled to be shut down within the next 5 years will be identified using the SFIA database and placed on schedule for transition into EM.

\subsection{NOTIFICATION}

The ORNL ER Facility Program Manager will be responsible for management of the SFIA database and for maintaining accurate updates to the SFIA database for ORNL facilities. The SFIA database will be the means by which potential candidate facilities for transfer into EM will be identified. The database includes a complete listing of all ORNL facilities and contains information such as facility condition (contaminated or decontaminated), status (operational, abandoned, etc.), program owner/funder (e.g., DP, EM), and responsible organization contacts (building manager). Information required for the SFIA database is contained in the "SFIA Database/Checklist." The overall checklist is designed to be completed by the responsible facility manager with assistance from various HSE organizations; Finance; and other support organizations. ORNL facility management organizations will be asked to provide data input for SFIA updates. Updates will be conducted biannually or when deemed necessary (i.e., mission change).

The ORNL ER Facility Program Manager, the ORNL Facility Transition Project Manager, and the ES Facility Transition Program Manager will evaluate revisions to determine whether or not transitioning would be appropriate. Updates of the SFIA database will be the mechanism used to initially notify the Office of Facility Transition and Management (EM-60) of the intent to transfer a surplus, contaminated facility. Agreement must be obtained between the ORNL ER Facility Program Manager, The Facility Transition Project Manager, and the Facility Transition Manager, and the Site DOE DP before any revisions are made to the SFIA database.

Following receipt of notification, an on-site screening review and risk ranking will be performed by EM-60 to determine whether or not a facility is an appropriate candidate for transfer. A screening review summary with recommendations will be prepared by DOE-Oak Ridge Operations EM-60 and forwarded to DOE Headquarters EM-60 for final determination. Any additional assessment activities required will also be identified in the summary. EM will formally notify DP of its determination. The decision will flow down through the designated channels to the appropriate ORNL Plant EM/DP organizations.

\subsection{RESOURCE IDENTIFICATION}

Following the determination by EM-1 that a facility is a candidate for transfer, the transition resource identification phase begins. A TWG composed of representatives from the ORNL 
Table 1. Schedules transition facilities

\begin{tabular}{|c|c|c|}
\hline Year & Facility name or number & Total number of facilities \\
\hline FY95 & Isotopes & 19 \\
\hline FY96-97 & $\begin{array}{l}3010 \text { BSR with } 16 \text { ancillaries } \\
7700 \text { TSF with } 11 \text { ancillaries } \\
\text { 3019B analytical lab } \\
7602 \text { integrated process }\end{array}$ & 31 \\
\hline FY98 & $\begin{array}{l}9201-3 \mathrm{E} \\
9201-3 \mathrm{~A} \\
3034 \\
3093 \\
7819 \\
3531 \\
3597 \\
9201-3 \mathrm{~J} \\
9204-3 \\
3121 \\
9201-2 \mathrm{~A} \\
2017 \\
9201-3 \mathrm{D}\end{array}$ & 13 \\
\hline FY99 & $\begin{array}{l}9207 \\
2061 \\
3542 \\
9201-3 B \\
2654 \\
3036 \\
7811 \\
9201-3 \mathrm{C} \\
9201-3 \mathrm{H} \\
3032 \\
3517 \text { BUP } \\
7860\end{array}$ & 12 \\
\hline FY00-01 & $\begin{array}{l}2000 \\
2001 \\
2024 \\
2087 \\
3110 \\
3505 \mathrm{~T} 1 \\
3505 \mathrm{~T} 2 \\
3503 \mathrm{~A} \\
7833 \\
9204-1 \mathrm{~K} \\
9201-3 \mathrm{G}\end{array}$ & 11 \\
\hline & & Total $=86$ \\
\hline
\end{tabular}


Transition Program, ORNL ER site management, and facility owner(s) and subcontractor organizations will define the scope of the transition effort. Support organizations such as Health, Safety, Environment, and Accountability and Facility Management will provide input. The TWG will address funding and FTE requirements in addition to provisions for S\&M and ancillary activities.

The ORNL ER Facility Program Manager with assistance from the TWG and support organizations, will develop a facility-specific transition plan that will identify the goals, activities, and organizational responsibilities.

\subsection{TRANSFER OF RESPONSIBILITY (FORMAL TRANSFER)}

Formal transfer of a facility occurs at the time specified in a Memorandum of Agreement (MOA) between the responsible program (e.g., DP) and EM-1. At that time, EM officially accepts line management and budgetary responsibility for the facility consistent with the MOA. In turn, the ORNL ER Transition Program will accept full responsibility prior to turnover to D\&D for S\&M and decommissioning of a facility. A site-level MOA will be generated by the facility owner with concurrence from the new owner (ORNL ER Transition Program). The MOA will document any conditions or stipulations agreed upon for transfer to occur. Upon agreement of the content, the document will be signed by both parties.

\subsection{FACILITY DEACTIVATION}

Actual deactivation activities are the responsibility of the operation(s) that occupies or has landlord responsibilities for a facility. The TWG will evaluate the deactivation scope by:

- interviewing process/knowledge personnel;

- evaluating data from the SFIA check sheets;

- involving support organizations to perform walk throughs, make recommendations, identify regulatory compliance concerns, provide existing data, and provide subject-matter expertise;

- estimating cost/FTEs/scheduling; and

- developing "control envelopes" that incorporate applicable environmental [e.g., National Environment Policy Act (NEPA)/Comprehensive Environmental Response, Compensation, and Liability Act (CERCLA)-like/Resource Conservation and Recovery Act (RCRA)] requirements; health, safety, and safeguards; and security requirements commensurate with the activities and materials involved with deactivating a facility.

The goal is to place a facility in a safe, environmentally sound, and "as-low-as-economically achievable" S\&M mode while the facility awaits final disposition. Facility-specific deactivation goals shall be developed as part of the legal compliance, safe shutdown, and transitional planning. Deactivation and compliance actions include all activities necessary to ensure regulatory compliance and deactivate, assess, and characterize facilities to reduce existing ES\&H vulnerabilities and minimize required S\&M activities while protecting the health and safety of 
personnel and the environment. The following activities are listed to illustrate those actions typical of a deactivation scope (list is not all-inclusive):

- remove or stabilize radioactive or chemical contamination source terms to reduce risk to a low-hazard level in accordance with DOE Order 5480.23, Nuclear Safety Analysis Reports;

- remove Special Nuclear Material to meet less-than-level Category IV in accordance with DOE Order 5633.3, Control and Accountability of Nuclear Materials, and comply with any guidance given by Nuclear Material Control and Accountability organization;

- remove (unless otherwise agreed) radiological, hazardous, and dangerous chemical inventories that are stored at the facility;

- ensure that confinement structures are structurally sound and in good repair to contain radionuclides or chemical contamination present in materials and preclude rain or snow melt water from intrusion;

- deactivate, consolidate, or cascade the facility heating, ventilation, and air conditioning systems so that only the necessary exhaust systems (fans, filters, monitoring, and sampling systems) will remain operational;

- control facility access to preclude personnel entry other than that required for periodic (e.g., quarterly) radiation and other surveys;

- prevent personnel from using the building and deactivate/clean all personnel support systems (e.g., offices bathrooms, lunchrooms, and ventilation systems);

- remove, to the extent possible, all combustible materials;

- deactivate loss prevention systems and all other electrical systems, retaining only those fire protection systems needed to ensure the integrity of the confinement structures;

- install and monitor systems needed for surveillance until D\&D activities begin;

- monitor systems at stations outside the contaminated facility, where possible;

- decontaminate/clean external surfaces of canyon vessels and internal surfaces of cells to remove significant radioactive or chemical residues;

- paint, as required, cell floors that have significant radionuclide retention to coat and fix contamination and minimize migration;

- leave in place, as a general rule, process and utility tanks, piping and deactivated electrical systems;

- $\quad$ remove for other use, as desired, separable capital equipment not in radiologically controlled zones unless equipment can be decontaminated and used elsewhere;

- remove all classified items (e.g., documents materials, and tools) and downgrade security requirements; 
- comply with Criticality Safety requirements;

- comply with RCRA and Toxic Substance Control Act requirements for hazardous materials; and

- establish and archive records necessary to reactivate systems/equipment to be used for D\&D including previous characterization efforts that can support D\&D.

A few select, critical drawings (e.g., ventilation, drains, piping, electrical) will be identified and used to document equipment/building/structure status and modifications. Any revised critical drawings will be used to create accurate as-built drawings of the final shutdown state.

\subsection{SURVEILLANCE AND MAINTENANCE}

S\&M activities will ensure that facilities are maintained in a safe, environmentally sound mode until disposition. Facility-specific S\&M plans including comprehensive planning, coordination, and oversight of all routine S\&M activities will be developed for transitioning facilities. The following items are listed to illustrate typical S\&M considerations; this list is not all inclusive.

- physical activities required to maintain the facilities in a safe condition and in compliance with all DOE orders and state, federal, and local regulations.

- facilities maintenance and surveillance as required by existing safety documentation which may include periodic surveillance of safety instrumentation, health physics monitoring, instrument calibration, and general maintenance essential to maintaining safety

- comprehensive planning, coordination, and oversight of all S\&M activities including direct and indirect supervision of personnel supporting the S\&M effort and tracking of cost and schedule performance against planned progress.

\subsection{DISPOSITION}

EM-60 will work to identify alternate uses for surplus facilities. If an alternate use for a facility (on an as-is basis) is identified, EM- 60 will coordinate the formal transfer of the EM site for alternate government or public use. However, if no use for a facility is identified, the facility will be transferred to the Office of Environmental Restoration (EM-40) for decontamination and decommissioning.

The ORNL Transition Program will no longer be responsible for a facility upon transfer to the ORNL D\&D Program for final disposition. The transfer will be documented by an MOA. EM-60 does not do cleanup work and then return the facility to the original landlord. 


\section{FACILITY TURNOVER AND ACCEPTANCE BY EM-40}

EM-60 will coordinate the turnover of inactive contaminated facilities to EM-40 through formal notification, stating whether the facilities have satisfied the EM-40 turnover criteria and identifying the proposed turnover date. EM-40 will respond formally, by either accepting, rejecting, or modifying the proposal following resolution and acceptance of formal notification form $E M-60$ for the facility.

While the EM-60 to EM-40 turnover protocol transpires, the ORNL Transition Program and ORNL D\&D Program will be working together to coordinate and ensure proper transfer of information so the facility turnover occurs smoothly at the site level.

By meeting the requirements listed below, facilities to be turned over to the ORNL D\&D Program for remedial action or D\&D will be put into an acceptable condition. Exceptions to the following requirements are possible and will be considered by EM-40 on a case-by-case basis.

1. Complete and document the final deactivation/shutdown of the facility. Provide current documentation (including drawings) of the deactivation/safe shutdown (if applicable) status of each facility. The documentation should address systems, such as the water, sewer, air, electric, gas, process (mechanical and chemical), and fire protection systems.

For a surplus facility, including its ancillary facilities, to be considered finally deactivated/shut down, the following conditions must be met by the proposing organization:

- Terminate programmatic facility operations and document that no future use of the facility is planned. This documentation (MOA) requires Operations Office and Headquarters Program Office signature.

- Document operational history of the facility (e.g., describe what processes, activities, chemicals, radionuclides, etc., were used in the facility.) Provide a report on the status/compliance of all regulatory commitments; for example, status of compliance with applicable regulations promulgated pursuant to statutes, such as Occupational Safety and Health Administration, RCRA, CERCLA-like, and NEPA.

- Provide a status of existing permits, including National Pollutant Discharge Elimination System, air permits, RCRA, and others.

- Provide a status of Interagency Agreements that identifies the terms and milestones of agreements pending and entered into by DOE with federal, state, and local agencies and the status of compliance. This includes settlement agreements, administrative or consent orders, and compliance plans to settle outstanding notices of violation.

- Provide a status of Corrective Actions by providing a list of corrective actions completed and outstanding from previous audits, inspections, and other similar activities (e.g., Tiger Team, Technical Safety Appraisal, Defense Nuclear Facility Safety Board, regulatory agencies, self-assessments, and business systems review), including identification of those items that need to be evaluated and reviewed with respect to the facility's surplus condition. Evaluate occurrence reports for trends or root causes. 
- For structures at the facility, provide the final radiological/hazardous materials survey records, final configuration and surveillance and maintenance requirements, drawings, specifications, procedures, manuals, and unplanned occurrences records applicable to the facility.

- For soil, surface water, and groundwater conditions at the facility, provide all existing data and reports that describe those conditions and the nature and extent of contamination therein. Also identify any known assessment requirements.

- Prepare or update a surveillance and maintenance plan or monitoring plan, including a cost estimate, consistent with final condition of facility at turnover.

- Make funding arrangements for up to 3 years until EM-40 funding is provided through the normal budgeting process.

2. Provide documentation demonstrating that structures at the facility are in a safe, secure condition, removing any immediate threats to human health and safety and the environment. Provide updated safety documentation for each facility, such as a description of the safety envelope in place. Provide the status of planned actions related to Safety Analysis Reports, Operational Safety Reports (OSRs), Technical Safety Requirements (TSRs), and implementing procedures covering the current status of the facility. Supply a copy of TSR surveillance program description and statement of compliance with TSRs. Provide the definition of the scope and estimate of the costs to bring the facility into compliance with OSRs in force, or recommended to be in force, and work packages to accomplish such compliance.

The following conditions must be met by the proposing organization (EM-60) for a facility to be acceptable to EM-40 with respect to radioactive and hazardous/toxic materials.

- Structure(s) and existing radiation monitoring systems as required, shall be in a physical condition adequate to contain and monitor potential release of any radioactive contamination, in accordance with DOE Order 5400.1, General Environmental Protection Program. The most current radiation contamination/hazardous and toxic materials survey of the facility and surrounding areas shall be provided.

- Security systems and procedures shall be adequate to prevent unauthorized entry to any structures at the facility.

- Special nuclear materials, reactor fuels, high-level waste, RCRA hazardous/mixed contaminated liquid wastes, and hazardous chemicals/materials that are stored at the facility shall be removed from the facility, unless otherwise agreed.

3. Provide an assessment of the compliance of the facility with respect to ES\&H regulatory requirements. 
4. Ensure that any structures at the facility and their required systems are structurally sound so as to permit deferred final decommissioning of such structures for up to 5 years after turnover. During this deferred period, EM-60 will be the responsible facility "holder" until EM-40 is ready for the transfer of responsibility. Exceptions will be made to this requirement in cases where adequate funding to cover needed repairs can be provided by EM-40. 


\section{GLOSSARY}

Contaminated Facility - any building, structure, equipment, pipe, pipeline, or storage container within or on which a radioactive and/or hazardous substance has been deposited, stored, disposed of, placed, or otherwise come to be located. Includes buildings, structures, etc., that supported operating program missions.

Contamination-unwanted radioactive and/or hazardous material that is dispersed (often in particulate form) on or in equipment, structures, objects, or soil. Contamination may be either surface or volumetric (i.e., radioactivity incorporated within a solid material); surface contamination may be either removable or fixed.

Deactivation-the process of permanently ceasing active operation at a DOE facility in a planned and controlled manner to support follow on decontamination and decommissioning activities. A process whereby legal compliance issues are resolved and nonessential systems and/or equipment in a shut down facility are de-energized, drained and flushed, isolated, or removed to minimize the long-term costs of maintaining the facility in a physically safe and environmentally secure condition. Includes the removal of fuel and stored radioactive and/or hazardous waste from the facility and implementation of appropriate facility safety requirements.

Decontamination-the process of removing or reducing the level of radioactive or hazardous material contamination from facilities, equipment, or soils by washing, heating, mechanical cleaning, chemical or electrochemical action, or other techniques.

Decommissioning - the process of safely removing from operation a facility contaminated with radioactive and/or hazardous materials so as to provide adequate personnel protection from exposure and to reduce the likelihood of contamination migration into soil, water, or air. Includes actions taken to stabilize, reduce, or remove radioactive and/or hazardous materials, or to demolish the facility. Decommissioning implies that no further use of the facility for its original or present purpose is intended.

Environmental Restoration-encompasses both the remediation of contaminated sites and the D\&D of contaminated facilities. Facility D\&D can involve structural decontamination for reuse, entombment, or decontamination and dismantlement.

Facility Owner-the organization(s) identified as being responsible for overseeing legal compliance and shutdown activities. The facility owner will identify resources such as a building manager, facility engineers, chemical operators, and other personnel knowledgeable of the facility to assist in the deactivation.

Landlord-the organizational element with responsibility for the overall capital improvement and common support activities at a DOE installation.

Surplus Facility-any facility (including installed equipment) that has no identified or planned programmatic use by the DOE operating program.

Surveillance and Maintenance-those activities conducted to ensure that a site or facility remains in a physically safe and environmentally secure condition, including periodic inspection 
and monitoring of the property, safety envelope, and required maintenance of barriers controlling access.

Turnover-the formal transfer of responsibility for a surplus facility within EM for either D\&D or alternate use.

Transition-the range of activities associated with the transfer of responsibility for a surplus facility from a DOE operating program to EM.

Transition Plan-a program management document that defines the goals, activities, and organizational responsibilities associated with the transfer of a surplus facility from a DOE operating program to EM. 
Appendix A

SECRETARY OF ENERGY MEMORANDUM 


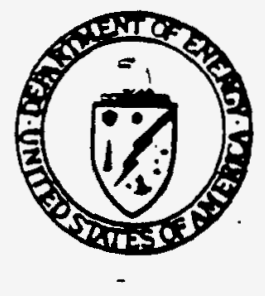

The Secretary of Energy

Washington, DC 20585

October 4, 1993

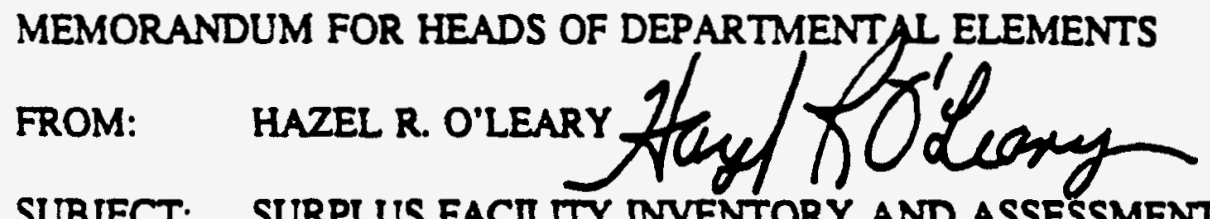

SUBIECT: SURPLUS FACIITY INVENTORY AND ASSESSMENT PROJECT

The Deparument of Energy is undergoing a major transformation as we shift priorities to reflect the end of the Cold War and beginning of new initiatives. This shift in mission priorities. combined with existing fiscal constraints. is resulting in a dramatic increase in the number of facilities that are becoming surplus to the Department's ongoing mission.

Some surplus facilities offer the potential for commercialization. These are valuable assets that should be identified and quickly transferred to the private sector to help minimize the economics impact of right-sizing on the communities surrounding our facilities. The remaining surplus facilities. many of which contain hazardous and/or radiological contamination. pose a liability to the Department. These contaminated facilities must be identified and properly managed by the responsible program office until they can be transferred to Environmental Management for deactivation, decontamination. and final disposition. including possible reuse.

1 have asked Tom Grumbly to quickly define the magnitude of this problem and develop a rational process for managing and making long-term plans for these facilities. The first step in this project is to develop an accurate inventory of contaminated surplus facilities by December 1993. consisting of those contaminated facilities that have been or should be declared surplus or are anticipared to become surplus over the next five years. In addition. we will need to assess the condition of these facilities to determine the order in which they should be transferred to Environmental Management and the resources needed to manage these facilities. This information is needed by March 31, 1994, to allow completion of budget planning for those facilities expected to transfer to Environmental Management in fiscal year 1996. Information on those facilities that are projected to transfer to Environmental Management after fiseal year 1996 will be needed by December 1994.

The information generated by this project will facilitate the timely transfer of contaminated surplus facilities from the "donor" programs to Environmental Management and enable us to properly plan and budget for this new work scope. Until a formal transfer can be accomplished. the "donor" program remains responsible and accountable for managing its contaminated surplus facilities.

The Surplus Facility Inventory and Assessment Project is an imporant first step in identifying assets that can be reused and liabilities that require long-term managemènt and cleanup. Please provide your full suppor to this high-priority initiative. 
Appendix B

SURPLUS BUILDING/STRUCTURE

IDENTIFICATION AND GROUPING FLOWCHART 


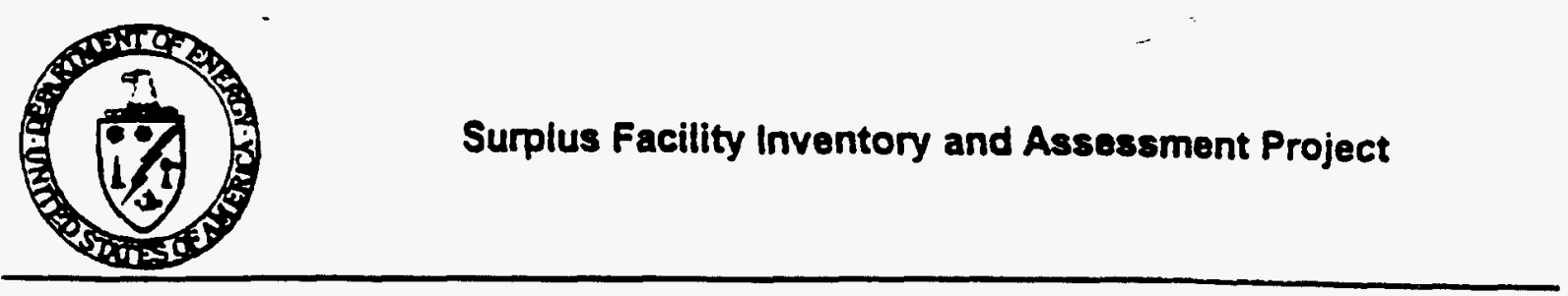

Surplus Building/Structure Identification and Grouping Guidance

The Surplus Facility Inventory and Assessment (SFIA) Project is designed to provide information on numbers, condition, and threats associated with comtaminated surplus facilities. This information will be used to define the magnitude of the surplus facility management and cleanup task and to make decisions on planning. budgeting. and management of contaminated surplus facilities. including ranking the facilities (using an adaptation of the Department's Safety and Heatth Five Year Plan threat-based priority model) for transition into the Environmental Restoration and Waste Management (EM) program. For the purpose of the SFIA, "surplus facilities" are the buildings/structures that are or will be no longer needed to support the Department's ongoing mission.

The terms "facility", "surplus", "process contaminated", and "non-process contaminated" have specific connotations within the contex of the SFIA project and are discussed briefly here. A complete list of terms and definitions is contained in Tab 4 of this notebook. The term "facility" is defined as a standalone building/structure or a group of related buildings, structures, utilities, and other assets associated with an operation or service. The term "surplus" is defined as those facilities that are or will be no longer needed to support the Department's ongoing missions. The term "process contaminated" is defined as contamination resulting from operational activities, (e.g., chemical separations, research activities, and product or waste storage activities). The term "non-process contaminated" is defined as contamination resulting from building/construction material, (e.g., asbestos tiles or insutation, lead paint) and PCB transformers/capacitors.

The difference between process and non-process comtaminated facilties is source of contamination. The source of contamination is important because it will determine which office has programmatic responsibility for decontamination and disposition. Decontamination and disposition of process contaminated surplus facilities, will as a nile, become Environmental Management's responsibility. Decontamination and disposition of non-process comtaminated surplus facilities, will in most cases. remain the responsibility of the current program sponsor or the site landlord. (i.e., these facilities will not transfer to EM for decontamination and disposition uniess EM is the landlord). It is expected that nonprocess contaminated facilities will be addressed by ongoing asbestos/pCenead paint abatement or removal programs funded by the sponsoring program and/or the site landlord. Disposition of these facilities is expected to occur via the existing requirements in DOE Order 4300.1C. Real Property Management, June 28, 1992.

The scope of the inventory phase (Phase 1) of the project includes identification of all buildings and structures, surplus or not and contaminated or not, for which the Department is responsible. The only sites excluded from the inventory are those of the Power Marketing Administrations. Certain types of structures are also excluded, (e.9., utillty poles, roads, bridges, and water tanks). A complete listing of exclusions is comained in the Project Exclusions section (Tab 3) of the notebook. Unless specifically excluded. all other Departmental facilities are included in the inventory identification phase of this project.

A comprehensive inventory is needed to ensure that all surplus facilities will be identified and accounted for. This will require that each site undertake an initial effort to prepare a complete listing of all buildings and structures not specifically exctuded from the project. Using the process described herein each building/structure will be assigned to one of the five groups described below. This can be achieved by going through the process depicted in the Surplus Facility Identification and Grouping Flowchart. All group designations must be coordinated with and concurred upon by the cognizant Secretarial Office. This will ensure that each building/structure is subject to a disciplined review of its status relative to the Department's ongoing missions. In addition, this process should help identify and resolve any 


\section{SURPLUS BUILDING/STRUCTURE IDENTIFICATION AND GROUPING FLOWCHART}
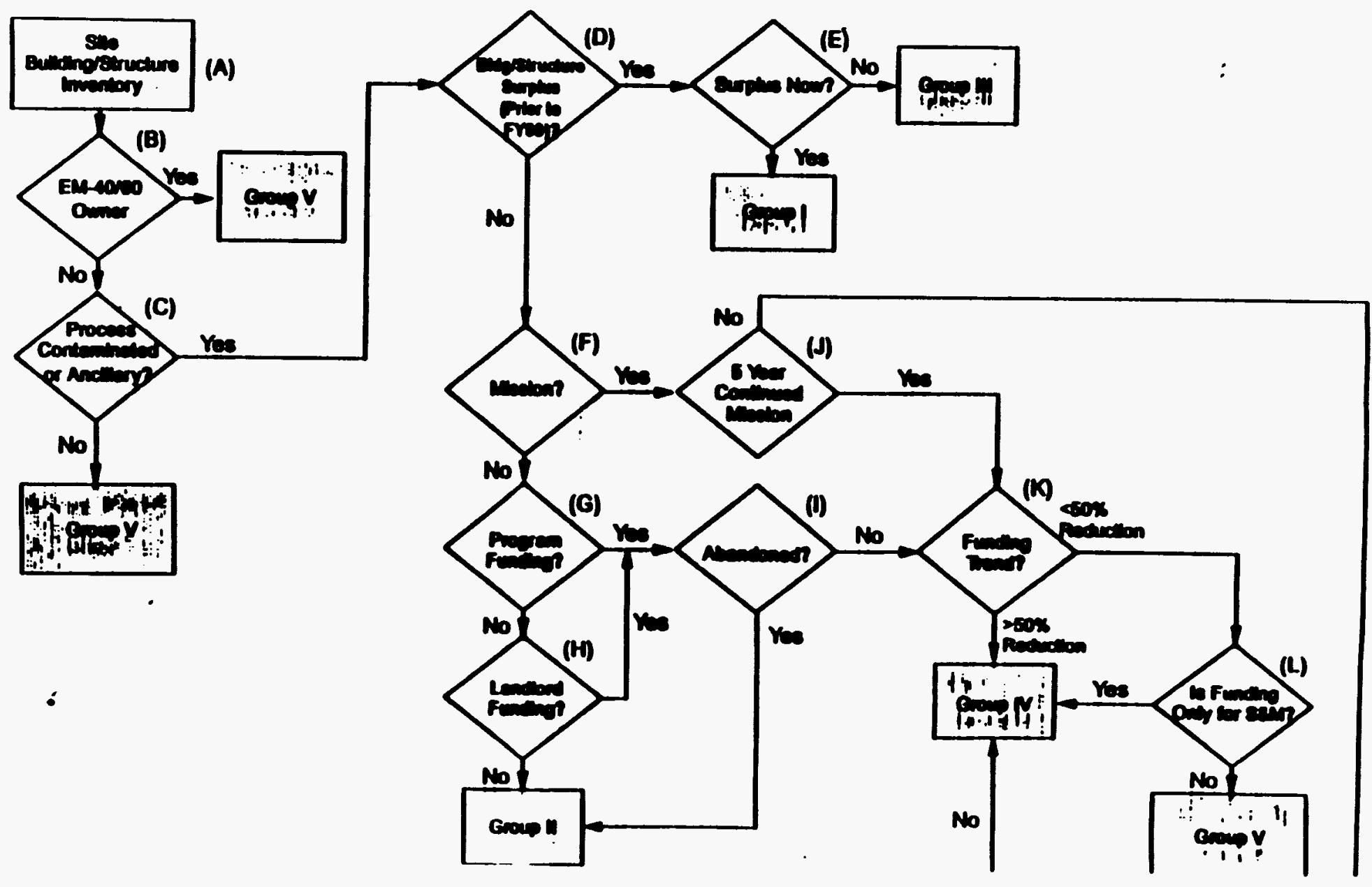
programmatic ownership issues. (e.9., no program owner identified, the wrong program owner identified, and multiple program owners identified). The end result will be a valid comprehensive inventory of facilities, subdivided into the following five building/struature groups:

\section{Group 1}

This group is for process contaminated buildings/structures that are now surplus and have been officially designated as surplus by the cognizant Secretarial Officer (SO). A memorandum from the SO to the Assistant Secretary for Environmental Restoration and Wasto Management (EM-1) designating a building/structure as surplus constitutes an official designation. EM-60 has prepared a list of process contaminated buildings/structures officially designated as surplus by the cognizant SO and will provide it to you for validation. Your office, in coordination with (and with the concurrence of) the appropriate SO. can place additional buildings/structures in Group I via Phase I of the SFIA process. Putting a building/structure in Group I will constitute an official designation of surplus for EM's purposes, and will make the building/structure eligible for transfer to EM. EM will not consider a building/structure for transfer unless it is placed in Group I, however, such designation does not guarantee transfer will occur in all cases. This will necessitate an annual review of the other groups to identify building/structures that should be moved to Group I.

\section{Group II}

This Group will capture process contaminated buildings/structures that should be declared surplus based on one, but more likely a combination of the following characteristics:

- No mission;

- No funding:

- No identified program/owner and not formally accepted by the site landlord, (i.e., orphaned building/structures); and

- Program owner identified but building/structure len unattended, with little or no surveillance and maintenance, (1.e., abandoned).

Group II is intended to be a temporary "holding area" for buildings/structures that have not been declared. surplus but based on the criteria above, probebly should be. Consequenthy, buildings/structures in Group II will need to be reevaluated as soon as possible (preferably prior to ranking) to determine if they should be placed in another Group, (i.e., Group I or iii). This is particularty important for orphaned or abandoned buildings. During the validation process, buildings/structures that should be on the Group II list will be identified and placed on this list, as appropriate. Orphaned buildings/structures will, by default. become the responsibility of the site landlord if no program owner can be identified. Group II buildings/structures must be moved to Group I if they are to be considered for transfer to EM.

\section{Group III}

This Group captures those process contaminated buildings/structures that will be declared surplus prior to FY 99. This group will define the magnitude of the future contaminated surplus building/structure problem and will be used for future planning and budgeting.

EM-60 will provide you with a preliminary list of buildings/structures that are projected to be declared surplus. This list, developed from information previously provided by Headquarters Secretarial Offices should be validated during Phase I. Using this list as a start, evaluate your process contaminated 
buildings/structures to detemine if they will be surplus prior to FY 99 . Evaluation criteria should include current mission and funding status, future mission and funding status. and replacement/demolition schedule. It is important that the evaluation for Group III buildings/struatures be unbiased and objective. (i.e.. a decision to place or not to place a bullding/strucaure in Group III should be based on facts and realistic projections versus proprietary and/or individual interests).

\section{Group IV}

This Group captures process contaminated buildings/structures that have one or more of the following attributes indicating they may become surplus:

- No mission projected beyond five years. (1.e., beyond FY 98);

- Declining budget. defined as, a greater than $50 \%$ reduction over a five year period, (i.e.. FY 90 througn FY 95); and

- Current funding is solely dedicated to Surveillance and Maintenance activities.

Group IV is intended to provide a "watch list" of process contaminated buildings/stnctures that. although not yet a candidate for surplus. appears to be heading that way. Group IV buildings/structures need to be reevaluated annually for any change in status.

\section{Group V}

All remaining buildings/structures identified in the site building inventory that have not been designated Groups I. II, III, or IV will be placed in Group V. Included will be buildings/structures that fall in the following categories:

- Non-contaminated (surplus or not);

- Non-process contaminated (surplus or not):

- Process-contaminated (not surplus); and

- Owned by EM-40/30.

Operation Offices will specifically identify those buildings/structures in Group $V$ (except those buildings/structures that EM-40 or EM-60 is the ownen that are surplus and non-process contaminated or surplus and non-contaminated.

\section{Process:}

The process description presented below should be used by each Site Coordination Team to guide the team through the identification and grouping phase of the Surplus Facility inventory and Assessment Process. Only buildings/structures identified as Groups I. II, III, will be subject to the assessment and ranking phase at this time. 
TO DETERMINE GROUP I AND GROUP III FACILTIES

SteP A. SITE BUILDING INVENTORY

Task: Identify and validate all buildings/structures at the site. (See Exclusion List at Tab 3)

Output: List of all buildings/structures associated with the site.

\section{SteP B EM-40/60 FACILITIES}

Task: From the list of buildings/structures identified in Step A, identify all buildings/structures that are owned by EM-40/80.

Output: Two lists of buildings/structures: One list includes the buildingsistructures that are owned by EM-40/60. These will be placed in Group V, and will not be subject to the assessment and ranking phase. The other list includes the remaining buildings/structures and is input into Step C.

STEP C. PROCESS CONTAMINATED OR ANCIILARY BUIILINGSISTRUCTURES

Task: From the list of facilities identified in Step B, identify all buildings and structures that are process contaminated and any ancillary buildings/structures, whether or not contaminated. that support them.

Output: Two lists of buildings/structures: A list of process contaminated buildings/structures and their ancillary and support buildings/structures comaminated or not (input to Step D). A list of buildings/structures that are not process contaminated (Group V). will remain the responsibility of the Secretarial Officer (SO) and/or the landlord, and will not be subject to the assessmemt and ranking phase.

\section{SIEP D. SURPLUS BUILDING/STRUCTURE PRIOR TO FY 92}

Task: From the list of building/structures that are process contaminated or ancillary to process contaminated buildings/structures as identified in step C, identify those buildings/structures which will be surplus prior to FY 99.

Output: Two lists: A list of buildings/structures which will be surplus prior to FY 99 (input to step E). A list of buildings/structures that will not be surplus prior to FY 99 (input to Step F).

\section{Step E. SURPLUS NOW}

Task: From the list of buildings/structures that will be surplus prior to FY 99, identify those that are surplus now.

Output: Two lists: A list of buildings/structures that are surptus now (Group 1). A list of buildings/structures that are not surplus now but will be within five years, (i.e.. prior to FY 99) (Group III). 


\section{TO DETERMINE GROUP II FACIUTIES}

\section{Step F. MISSION}

Task: From the list of buildingsstructures that will not be surplus prior to $F Y 99$, as identified in stop D, identify those with a mission and those that do not have a mission.

Output: Two lists: A list of buildings/structures that have a mission (input to Step J). A list of buildings/struaures that do not have a mission (input for Step G).

SteP G. PROGRAM FUNDING

Task: From the list of buildings/structures that have no mission, as identified in step F, identify those buildings/structures that currently have program funding. and those that do not.

Output: Two lists: A list of buildings/structures that have program funding (input for Step I). A list of buildings/structures that do not have program funding (input to Step $\mathrm{H}$ ).

\section{Step H. LANDLORD FUNDING}

Task: From the list of buildings/structures that have no program funding, as identified in step $G$. identify those building/structures that currently have landlord funding, and those that do not.

Output: Two lists: A list of building/structures that have landiond funding (input to Step I). A list of buildings/structures that do not have landlord funding. The list of buildings/structures that have no mission. prooram funding, and/or landlord funding are Group II buildings/struatures.

\section{Step I. ABANDONED}

Task: From the list of buildinge/structures that have program funding (Step G) and landiond funding (Step H), identify which buildings/struatures are abandoned. (Use definition provided)

Output: Two lists: A list of buildingerstructures that are abandoned (Group II). A list of buildings/structures that are not abandoned (input to Step $K$ ).

\section{TO DETERMINE GROUP N BUILOINGSISTRUCTURES}

\section{Step J. FIVE YEAR CONTINUED MISSION}

Task: From the list of bulldings/structures having a mission, as identfied in Step F, identify those buildings/structures which are expected to have their mission comtinued for five years, and those that are not.

Output: Two lists: A list of buildings/structures that are expected to have a mission for the next five years (input to Step K). A list of buildings/structures that are not expected to have a five year continued mission (Group IV). Group IV buildings/structures will not be subject to the assessmem and ranking phase at this time. 
Appendix C

\section{SURPLUS FACILITY INVENTORY ASSESSMENT} PROJECT CHECKLIST 
C-3

Surplus Facility Inventory and Assessment Project

Surplus Facility Inventory and Assessment Checklist

Outline

I. Identfication and Grouping Information

II. General Information

III. Radiological Information

N. Hazardous Non-radiologieal Contamination Information

v. Waste and Hezardous Material Inventory Information

V. Tank Information

Vi. Safeguards and Security Information

Vili. System Condition Information

IX. Stand-Alone Tank Information 
Step K. FUNDING TREND

Task: From the lists of buildings/structures having a five year continued mission (Step J) and those that are not abandoned (Step 1), identify the funding trend for each building/structure.

Output: Two lists: A list of building/structures with an expected funding reduction greater than $50 \%$ (Group IV). Group IV buildingsstructures will not be subject to the assessment and ranking phase at this time. A list of buildings/structures with an expected funding reduction less than $50 \%$ (input for Step L).

\section{STOP L. IS FUNDING ONLY FOR SURVEILLANCE AND MAINTENANCE ACTIVITIES}

Task: From the list of building/structures with a less than $50 \%$ reduction in funding, identified in step $K$, identity which buildings/structures only have S\&M funding, and those that have funding for other activities as well.

Output: Two lists: A list of buildings/structures that are being funded solely for SeM activities (Group IV). Group IV buildings/structures will not be subject to the assessment and ranking phase at this time. A list of buildings/structures receiving funding for S\&M and additional mission related activities (Group V). Group V buildingesstructures will not be subject to the assessment and ranking phase of this time. 


\section{SECTIONI.}

\section{IDENTIFICATION AND GROUPING INFORMATION}

\begin{tabular}{ll}
\hline PURPOSE: & $\begin{array}{l}\text { Provide identification information on assets (buildingalstructures and tanks), } \\
\text { including grouping the assots into Groups I through V. } \\
\text { Identify ancillary buildings/structures that } \\
\text { contaminated buildings/atructures. }\end{array}$ \\
USE: & $\begin{array}{l}\text { To establish a complete liating with pertinent basic identification information on } \\
\text { assets. }\end{array}$
\end{tabular}

Is the asset:
ㅁ Building/structure
口 Stand-alone tank

If the asset is a building/atructurs, complete Soctions I through V and VI through VIII of this checkliat If the assot is a stand-alone tank, complote Sections $I$ and $I X$ of this checkllat.

I-1. Identification:

Area (if applicable):

Asset Name:

Asset Manager.

RPIS Class :

CAS Identification Number

Owner - Secretarial Office:

Owner - Cperations Office Program/Organizational Element

Responsible Contractor Organization:

Specify the Group (See EM-60 Group definitions) of this asset
口 Group I
口 Group II
口 Group III
口 Group IV
口 Group V

If the asset is in Groups I-HV, skjp to queation 1-6.

If the asset is in Group $V$, only answor queations 1-2, 1-3, 1-4, 1-6, 1-6, 1-7 of thits checkliat.

1-2. Is the Group $V$ asset owned by either EM-40 or EM-60?
ㅁ Yes
口 No
If yes, skip to question 1-6.

1-3. Is the Group V assot

口 Surplus Now $\square$ Not Surplus Now

14. Is the Group $V$ asset non-process contaminated?

$\square$ Yes $\square$ No Unknown

1-5. Identify the Headquarters Secretarial Office providing primary program funding.
D DP Defense Programs
口 EE Energy Efficiency
口 EM-30 Waste Mgt
RW Civ Rad Waste Mgt
口 EM-40 Env Res/D\&D
口 EM-50 Tech Dev/Trans
口 ER Energy Research
RW Civ Rad Wast
Source of information (Include details.)
口 Interview/personal knowledge
口 FE Fossil Energy
口 NE Nuclear Energy
口 EM-60 Fac Transition
口 None
Unknown
口 Document 


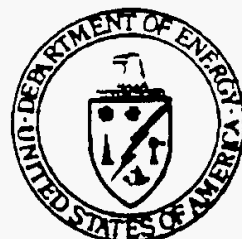

\section{Surplus Facility Inventory and Assessment Project}

Sito:

RPIS Number

Row. 19
Dato:

Propared by:

1-6. What is the current operational status of the asset (select only one status):
口 Operating
ㄴ Stand by
a Abandoned
- Deactivated
口 Shutdown
a Unknown

$\square$ Other-Specify:

D Decon \& Decomm

Source of Information (Include dotalk.)

$\square$ Interview/personal knowledge $\square$ Document

1-7. History:

Calendar Year Built

Fiscal Year Operation Ended or is Projected to End
Source of Information (Include dotatle.)
$\square$ Interview/personal knowledge $\square$ Document
D Walkdown

[Complete the following three questions (1-8, 1-8 and 1-10) onhy for aseste in Groups I-H.]

1-8. List any other assets for which this asset provides direct support

\begin{tabular}{|r|r|}
\hline Asset name & RPIS Number \\
\hline & \\
\hline & \\
\hline & \\
\hline & \\
\hline & \\
\hline
\end{tabular}

1-9. List any ancillary asset providing direct support to this asset.

\begin{tabular}{|r|l|}
\hline Asset namo & RPIS Number \\
\hline & \\
\hline & \\
\hline & \\
\hline & \\
\hline & \\
\hline & \\
\hline
\end{tabular}

1-10. List any other assets that are contiguous (e.g., shared wall(s)) to this aseat.

\begin{tabular}{|c|c|}
\hline Asset name & RPIS Number \\
\hline & \\
\hline & \\
\hline & \\
\hline & \\
\hline & \\
\hline & \\
\hline
\end{tabular}


Site:

RPIS Number:

Rov. 11
Date:

Propared by:

\section{SECTION II:}

\section{GENERAL INFORMATION}

\begin{tabular}{ll}
\hline PURPOSE: & $\begin{array}{l}\text { Provide basic information on process contaminated buildings/structures and } \\
\text { associated cost for surveillanco and maintenance. }\end{array}$ \\
USE: & $\begin{array}{l}\text { To establish an up-to-date listing with pertinent basic data on process- } \\
\text { contaminated bulldingslatructures. }\end{array}$
\end{tabular}

11-1. Is the entire building/structure or only a portion of it surplus now (or within five years)?

\begin{tabular}{|l|c|c|}
\hline & Surplus Now & Surplus within Five Years \\
\hline Portion of Building/Structure & $\square$ & $\square$ \\
\hline Entire Building/Structure & $\square$ & $\square$ \\
\hline
\end{tabular}

II-2. Type of Construction:
口 Reinforced Concrete
ㅁ Concrete/Masonry Block
口 Brick

Source of Information (Include dotalis.)

Source of Information (Include dotails.)

ㅁ Interview/personal knowledge a Document

11-3. Asset Dimensions:

Footprint (square feet)

Total square feet

Total no. of floors

Source of Information (include dotails.)

$\square$ Interview/personal knowledge $\square$ Document $\square$ Walkdown 


Surplus Facility Inventory and Assessment Project

114. What is the FY93 actual and unfunded direct and indirect Surveillance and Maintenance (S\&M) cost for this building/structure? If available. provide a cost estimate for each of the elements in the shaded blocks below. Othenwise, provide the totals for Direct and Indirect costs. If S\&M cost estimates cannot be obtained on a building/structure level, provide S\&M cost estimates on a facility level, specifying (in the remarks section) the group of buildings/structures included in the total.

\begin{tabular}{|c|c|c|c|c|}
\hline & \multicolumn{2}{|c|}{ Actual } & \multicolumn{2}{|c|}{ Untunded } \\
\hline & $\begin{array}{l}\text { Direct } \\
(\mathbf{S 0 0 0 )}\end{array}$ & $\begin{array}{c}\text { Indirect } \\
(5000)\end{array}$ & $\begin{array}{l}\text { Direct } \\
(5000)\end{array}$ & $\begin{array}{c}\text { Indirect } \\
(\$ 000)\end{array}$ \\
\hline Surveillance & & 18 & 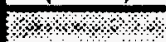 & $\because \cdots$ \\
\hline Safeguards and Security & & 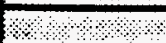 & 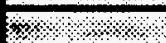 & $\%$ \\
\hline Environment, Safety and Health & i. & \%। & 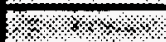 & 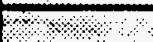 \\
\hline Custodial Fees & & \%?: & $1 / 2 \%$ & 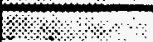 \\
\hline Backlog of Maintenance and Repair & ৷ । & 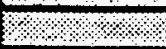 & 6.1 .6 .2 & . \\
\hline Maintenance & $1 \%$ & $\% \%$ & \%:? & \% \\
\hline Emergency Preparation & कि। & $18 \% 1 \%$ & 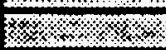 & 8 \\
\hline Utilities & $10 \%$ & $\sqrt{18.28}$ & 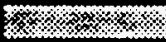 & 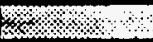 \\
\hline Leases & & 18 & $1 \%$ & 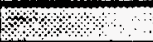 \\
\hline Property Taxes or fees & $1.8 \%$ & 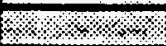 & . & 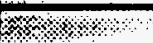 \\
\hline Other (specify) & & 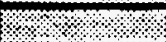 & m: & 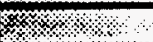 \\
\hline Other (specify) & $8: 1.4$ & 格: & - & 17 \\
\hline Other (specify) & & 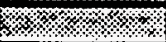 & $-\infty$ & 桨 \\
\hline
\end{tabular}

\begin{tabular}{|l|l|l|l|l|}
\hline Direct (S000): & Actual: & & Untunded: & \\
\hline Indirect (S000): & Actual: & & Unfunded: & \\
\hline
\end{tabular}

What is the basis for this S\&M cost estimate?
actual
D s per sq foot
ㅁ Percent of operating budget
Percent of replacement value
O Other - Specify:

How much of this cost is for the Backlog of Maintenance and Repair (BMR) (in S000)?

s.

Source of Information (Include detaile)

$\square$ Interview/personal knowlodge

Document

Walkdown 


Surplus Facility Inventory and Assessment Project
RPIS Number:
Rev. 11

II-5. Assuming the building/structure will cease mission-related operations within the next five years, are there additional annual and one-time activities (not addressed in the preceding two questions) that would be necessary to prevent the building/structure from further deterioration and to maintain it in an environmentally acceptable manner? If yes, please provide cost (do not include one-time costs associated with characterization requirements andvor correction of immediate and serious problems identified in subsequent sections of this checklist):

口 Yes serious problems identified

Additional annual cost. \$ Additional one-time cost $\$$

Briefly describe one-time cost actrvities:

Source of Information (Include details.)

$\square$ interview/personal knowledge

Document $\square$ Walkdown

II-6. What is the most significant regulatory compliance status of this building/structure?

口 Major non-compliance with Federal, State, Local laws

Major non-compliance with interagency agreements

Marginal or isolated non-compliance with law

Marginal or isolated non-compliance with interagency agreements

$\square$ Deviation from documented but not law-based requirements (e.g., DOE Orders, Best Management Practices)

$\square$ None of the above

Briefly describe noted non-compliance:

Source of information (Include dataila.)

$\square$ Interview/personal knowledge $\square$ Document $\square$ Walkdown

II-7. Is there current RCRACERCLA activity ongoing at the building/structure?

$\square$ Yes $\square$ No Unknown

Briefly describe RCRAVCERCLA activity:

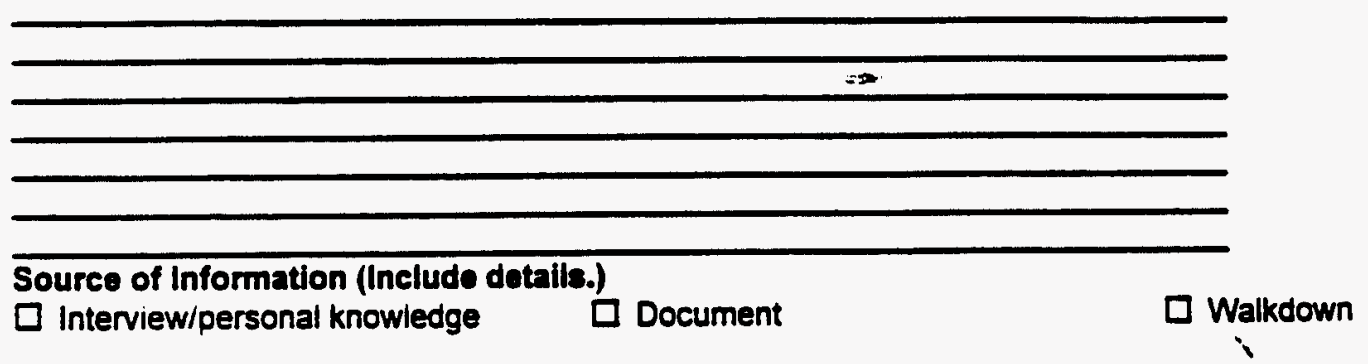




Surplus Facility Inventory and Assessment Project
Sito:
Rev. 11

11-8. Identify those worker safety hazards which may impact surveillance and maintenance and/or deactivation workers after the transition of the building/structure to EM-60 which may result in any of the following:

Catastroohic Iniuodlliness - Permanent total disability, chronic or irreversible illness, extreme overexposure (1000 remlyr) or death.

Critical Iniundlliness - Permanent partial disability, temporary total disability (greater than 3 months). or serious exposure (100-1000 remyr).

MarainaL_niundlliness - Hospitalization, temporary reversible illness, limited disability (less than 3 months), exposure from limits up to 100 remyr.

Nealiaible Iniurulllness - Temporary reversible illness requiring minor supportive treatment, exposure less than 20 percent of limits.

\begin{tabular}{|c|c|c|c|c|}
\hline Hazard & $\begin{array}{l}\text { Catastrophic } \\
\text { Injury/lineses }\end{array}$ & $\begin{array}{c}\text { Crition } \\
\text { Injuryllinasea }\end{array}$ & $\begin{array}{c}\text { Marginel } \\
\text { Intury/nimeese }\end{array}$ & $\begin{array}{l}\text { Negligitiole } \\
\text { Injury/lineses }\end{array}$ \\
\hline Wonfined Spacen & a & 8 & 64 & +6/ \\
\hline D PhyaControls (Noles, visual, climats, ote) & $\square$ & 口 & $\square$ & 口 \\
\hline 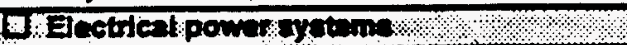 & max & $\mathbf{r} \mathbf{x}_{\mathbf{x}}$ & 68 & aro \\
\hline D Hoistng/rigging Oparatione & 口 & 口 & 口 & 口 \\
\hline 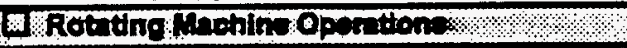 & an & 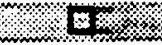 & 8 & $\mathrm{PH}$ \\
\hline D High Proseurs Syctams & 口 & $\square$ & 口 & 口 \\
\hline 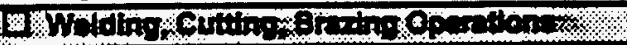 & m. & 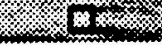 & 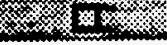 & E \\
\hline D Walking and Workdne Surteces & 口 & $\square$ & 口 & $\square$ \\
\hline 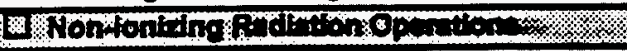 & 8 & 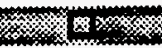 & 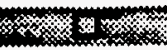 & Eto \\
\hline D Chomical Expoeur & 口 & 口 & $\square$ & $\square$ \\
\hline 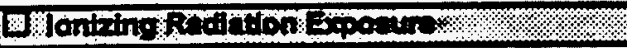 & (x) & 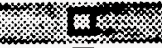 & 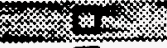 & 1 \\
\hline D Other - see remarke & 口 & 口 & 口 & $\square$ \\
\hline
\end{tabular}

a None $1 \%$

Describe the hazards listed above and provide an asseasment of the likelihood of their occurrence, i.e., low. medium, high (once in 100 years, once in ten years, once in one year):

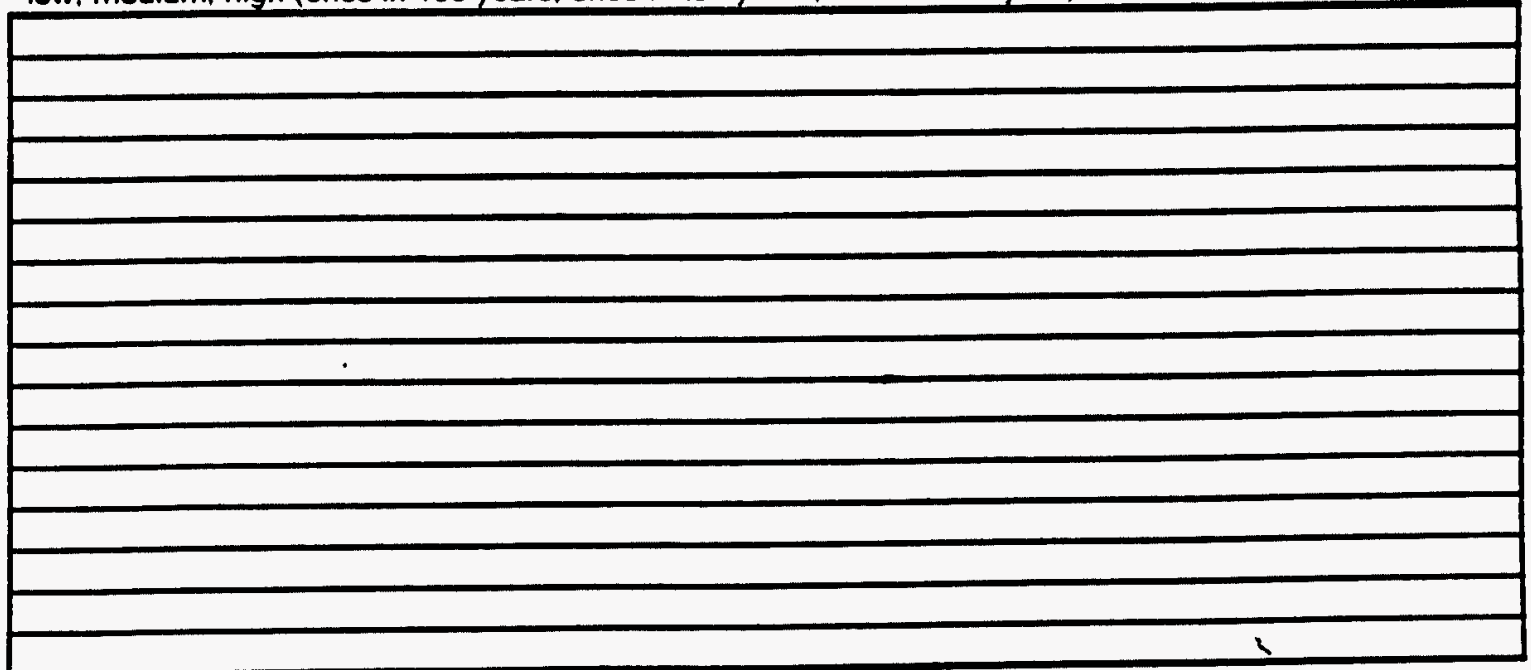

Source of Information (Include dotails.)

$\square$ Interview/personal knowledge

Document

Walkdown 


Surplus Facility Inventory and Assessment Project
RPIS Numbar:
Rov. 11

\section{SECTIONIII. RADIOLOGICAL INFORMATION}

$\begin{array}{ll}\text { PURPOSE: } & \text { Provide a basic radiological profile of the building/structure. } \\ \text { USE: } & \text { To charactertze the radlological conditlons of the building/atructure. } \\ & \text { To use in the assessment of basic radiological hazards and riske. }\end{array}$

NOTE: THIS SECTION OF THE CHECKLIST SHOULD BE COMPLETED IN CONJUNCTION WITH SITE RADIOLOGICAL SPECIALISTS.

III-1. Identify the major radionuclides processed, stored, or used in the building/structure now or in the

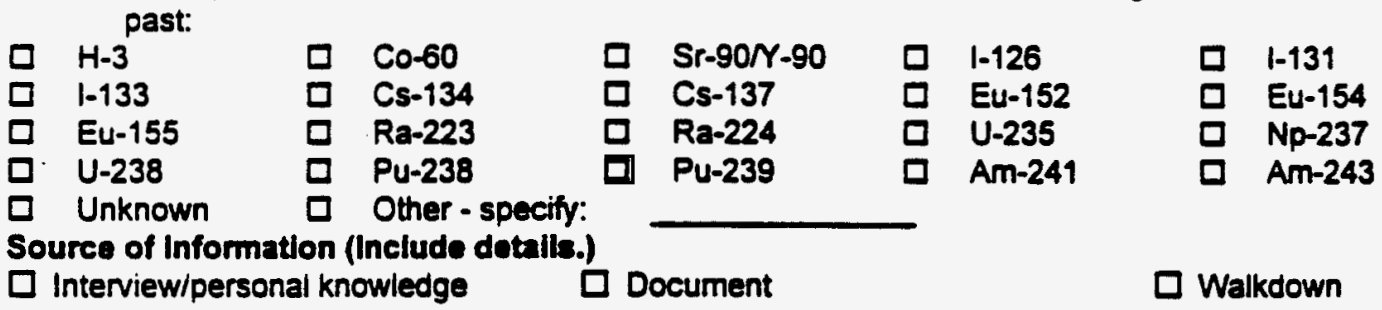

III-2. Does the building/structure have radiological contamination?

口 Yes $\square$ No Unknown

Source of Information (Include dotaile.)

$\square$ Interview/personal knowledge $\square$ Document $\square$ Walkdown

If 'Unknown', provide the preliminary cost estimates for characterizing unknown radiological contamination:

$S$

Source of Information (Include detaib.)

$\square$ Interview/personal knowledge $\square$ Document

Not available

III-3. Mark the appropriate box for each item below to provide a summary of the radiological status of the building/structure. Use definitions in the DOE Radiological Control Manual.

\begin{tabular}{|c|c|c|c|c|c|}
\hline & \multicolumn{5}{|c|}{$\%$ of Building/structure Posted } \\
\hline Postinge & None & $\begin{array}{l}\text { Leas } \\
\text { than } 10 \%\end{array}$ & $\begin{array}{l}\text { Betw } 10 \% \\
\text { and } 40 \%\end{array}$ & $\begin{array}{l}\text { Bend } 40 \% \\
\text { and } 75 \%\end{array}$ & $\begin{array}{l}\text { Greater } \\
\text { than } 75 \%\end{array}$ \\
\hline Radiation Arvas: & 8 & $18 \%$ & $-\mathbf{D}$ & 16\% & \%1. \\
\hline High Radiation Aroas & $\square$ & $\square$ & $\square$ & 口 & Q \\
\hline Yery High Radiation: Arens. & 8 & E & 8 & 8 & s \\
\hline Radioactive Storage Areas & $\square$ & $\square$ & $\square$ & $\square$ & $\square$ \\
\hline Contamination Areas: & 8 & a & D. & as & 6 \\
\hline High Contamination Aran & $\square$ & $\square$ & $\square$ & $\square$ & $\square$ \\
\hline Flxed Concamination Arons & 8 & $Q$ & 8 & $\$$ & 8 \\
\hline Airbome Radioactivity Ares & $\square$ & $\square$ & $\square$ & $\square$ & $\mathbf{\square}$ \\
\hline
\end{tabular}

Source of Information (Include details.)

$\square$ Interview/personal knowledge $\square$ Document $\square$ Waikdown 


Surplus Facility Inventory and Assessment Project

1II-4. Where is the majority of contamination located, is it fixed and/or removable, and how is it controlled?

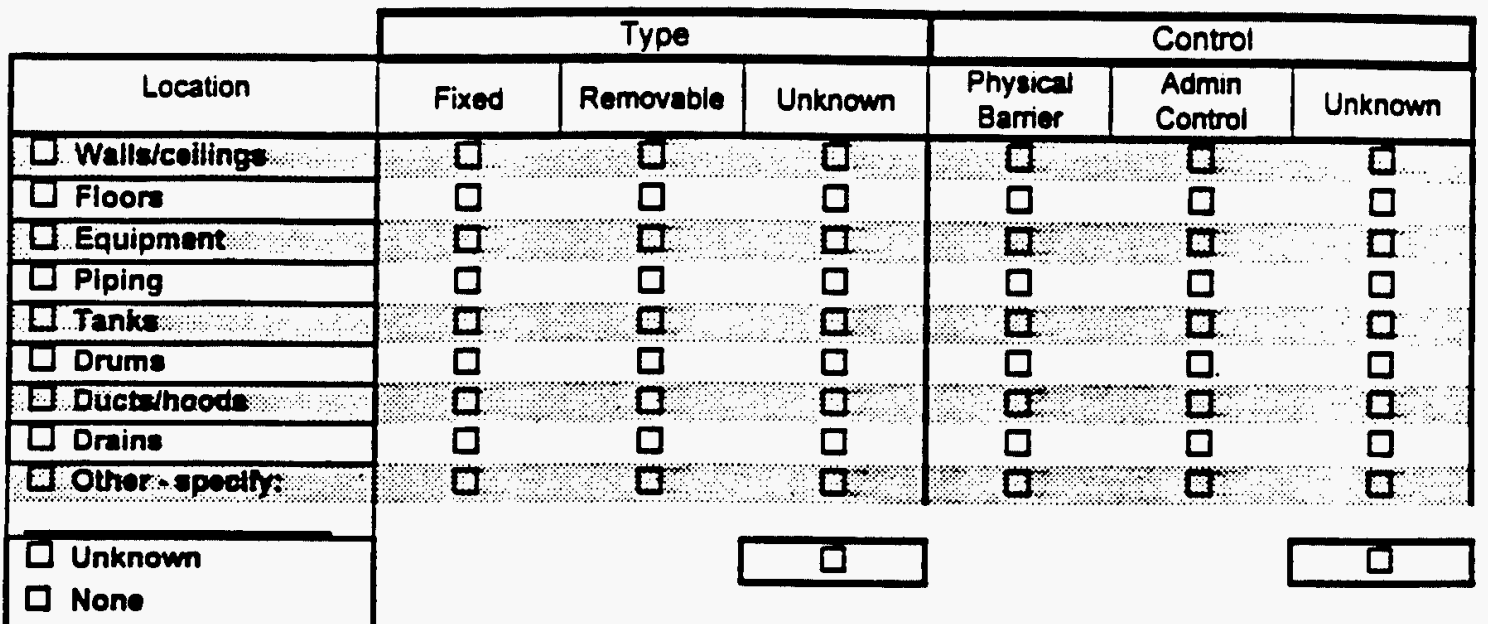

Source of Information (Include dotalis.)

$\square$ Interview/personal knowledge $\square$ Document $\square$ Walkdown

III-5. Did the building/structure have any planned/unplanned radiological releases resulting in contamination of.

$\begin{array}{llll}\text { Soil } & \square \text { Yes } & \square \text { No } & \square \text { Unknown } \\ \text { Ground water } & \square \text { Yes } & \square \text { No } & \square \text { Unknown } \\ \text { Surface water } & \square \text { Yes } & \square \text { No } & \square \text { Unknown } \\ \text { Air } & \square \text { Yes } & \square \text { No } & \square \text { Unknown }\end{array}$

If "Yes", describe:

Source of Information (Include detaib.)

$\square$ Interview/personal knowledge $\square$ Document $\square$ Walkdown

III-6. Does any radiological contamination or radiological source present an immediate and serious problem for (describe condition in remarks).

\begin{tabular}{|c|c|c|c|c|}
\cline { 2 - 5 } \multicolumn{1}{c|}{} & Worker & Public & Environment & Building/Struct \\
\hline Yes & $\square$ & $\square$ & $\square$ & $\square$ \\
\hline No & $\square$ & $\square$ & $\square$ & $\square$
\end{tabular}

Yes $\square$ No

If available, provide preliminary cost estimate for correcting all immediate and serious.problems identified (\$000): 口Not available

Source of Information (include dotalls.)

$\square$ interview/personal knowledge $\square$ Document $\square$ Walkdown 


Surplus Facility Inventory and Assessment Project
Site:
Rev. 11

\section{SECTIONIY. \\ HAZARDOUS NONFRADIOLOGICAL CONTAMINATIONINEORMATION}

PURPOSE: Provide a basic non-radiological profile of the building/atructure.

USE: To characterize the non-radiological conditions of the building/atructure.

To use in the assessment of basic non-radiological hazards and risks.

NOTE: THIS SECTION OF THE CHECKLIST SHOULD BE COMPLETED IN CONJUNCTION WITH SITE ENVIRONMENTAL SPECIALISTS.

IV-1. Identify the major hazardous non-radiological substances processed, stored or used in the building/structure now or in the past:

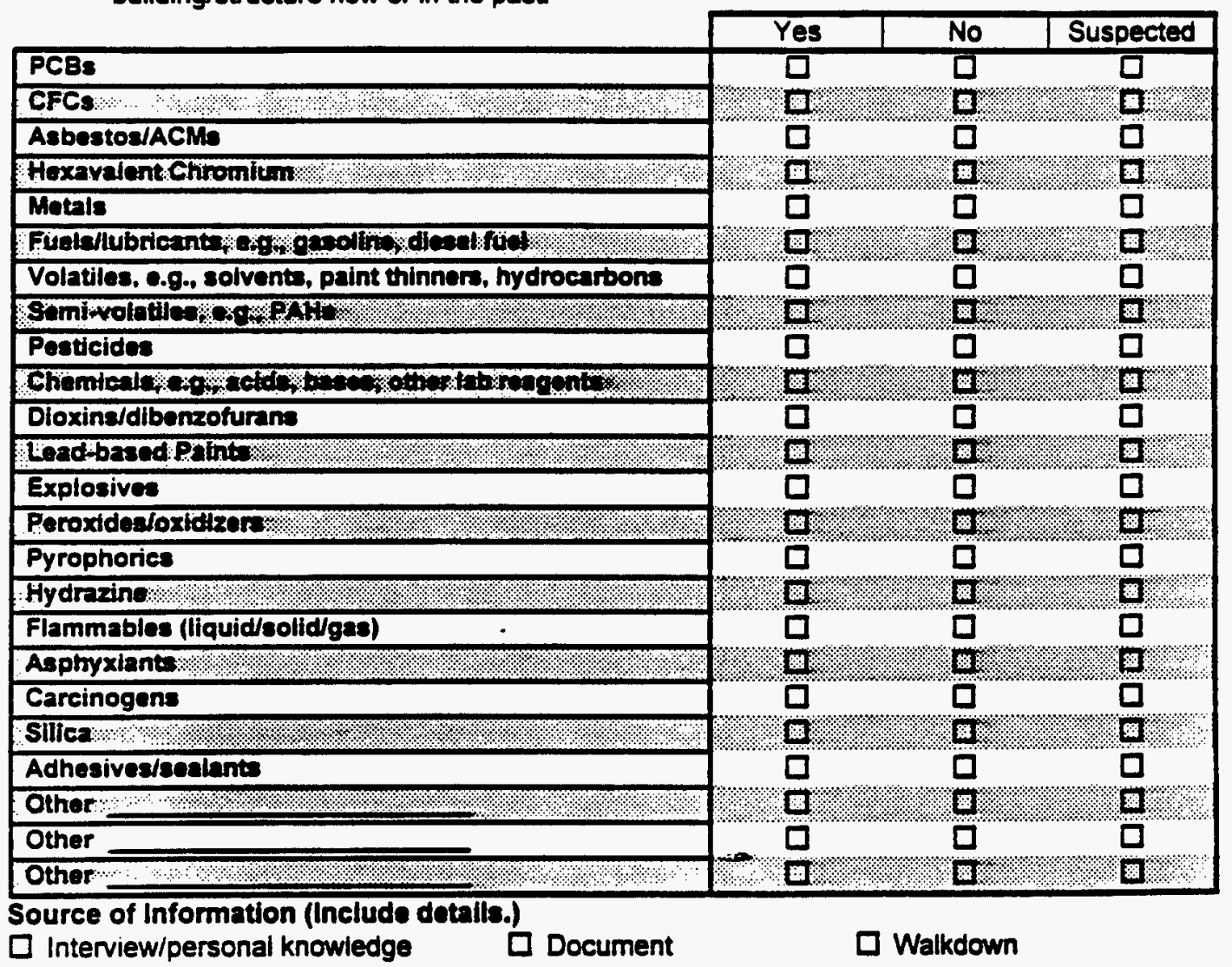

IV-2. Does the building/structure have any hazardous non-radiological contamination?

$\square$ Yes $\square$ No $\square$ Unknown

If 'Unknown', provide the preliminary cost estimates for characterizing unknowns (in \$Q00):

$$
S
$$

Source of Information (Include details.)

$\square$ Interview/personal knowledge $\square$ Document
Not Available

Walkdown 
C-14

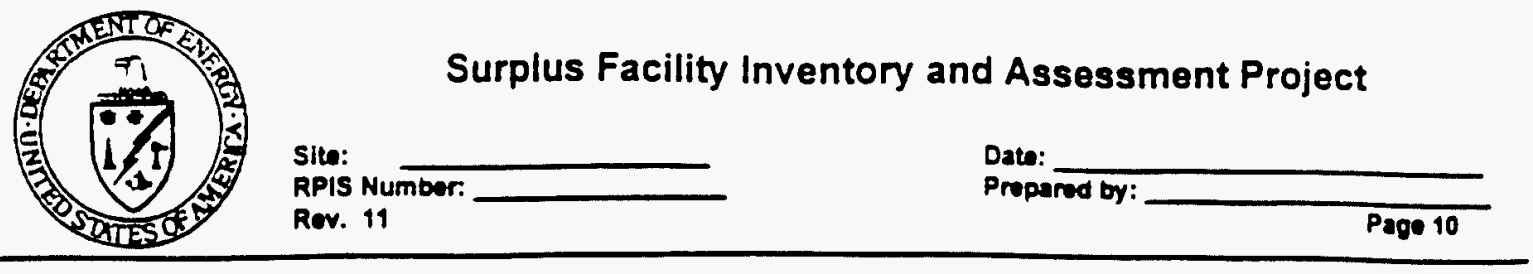

IV-3. Identify the areas of the building/structure with known hazardous non-radiological substance contamination and how it is currently controlled:

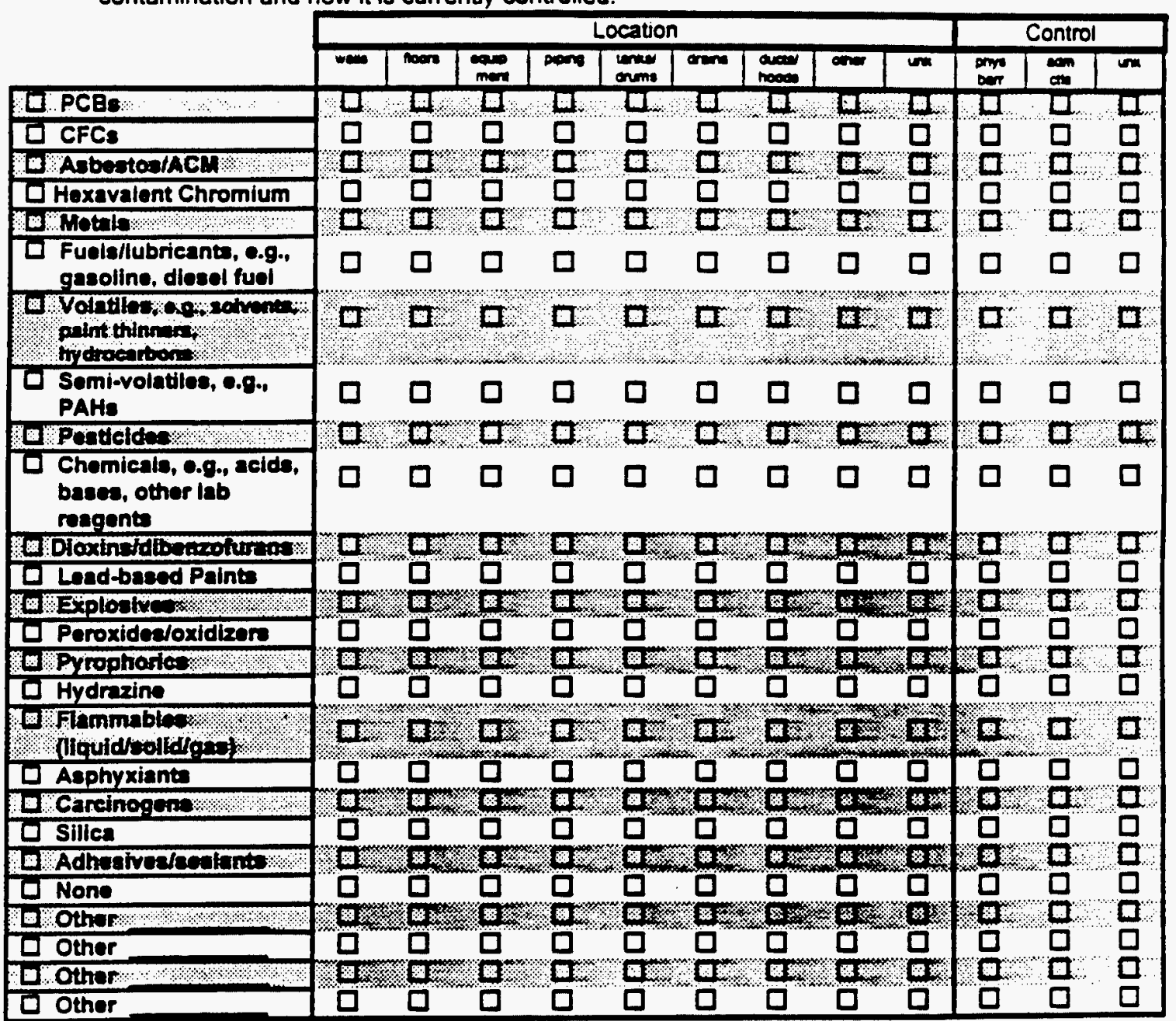

Source of information (Include details.)

$\square$ Interview/personal knowledge

$\square$ Document $=$

Walkdown 
Surplus Facility Inventory and Assessment Project

Site:

RPIS Numbor:

Rev. 11
Dato:

Prepared by:

IV 4. Did the building/structure have any planned/unplanned hazardous, non-radiological releases that resulted in contamination to:

Soil

Ground water

Surface water

Air

Describe "Yes" responses: $\square$ Yes

$\square$ Yes

$\square$ Yes

$\square$ Yes $\square$ No

$\square$ No

$\square$ No

$\square$ No $\square$ Unknown

[ Unknown

U Unknown

$\square$ Unknown

Source of Information (Include detaile.)

$\square$ Interview/personal knowledge

$\square$ Document

$\square$ Walkdown

IV-5. Does any hazardous non-radiological contamination present an immediate and serious problem for (describe condition in remarks).

\begin{tabular}{|c|c|c|c|c|}
\cline { 2 - 5 } & Worker & Public & Environment & Building/Struct. \\
\hline Yes & $\square$ & $\square$ & $\square$ & $\square$ \\
\hline No & $\square$ & $\square$ & $\square$ & $\square$
\end{tabular}

If yes, does an Action Plan exist (describe actions in remarks)?

Y Yes $\square$ No

If available, provide preliminary cost estimate for correcting all immediate and serious problems identified (\$000): DNot avaitable

Source of Information (Include dotalis.)

$\square$ Interview/personal knowiedge

$\square$ Document

Walkdown 


\section{C-16}

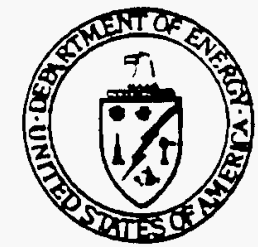

Sits:

RPIS Numbor:

Rev. 11

Date:

Propared by:

Surplus Facility Inventory and Assessment Project

Page 12

\section{SECTIONV.}

WASTE AND HAZARDOUS MATERIAL INVENTORY INOORMATION

PURPOSE: Provide a basic waste and hazardous material profilo for the buildinglatructure.

USE: $\quad$ To Identify radloactive, chomical and mixed hazardous wantes.

To identify potontlally excess chemical materials.

To assess the riak posed by waste and hazardous material inventory.

NOTE: THIS SECTION OF THE CHECKLIST SHOULD BE COMPLETED IN CONJUNCTION WITH SITE ENVIRONMENTAL SPECIALISTS.

V-1. Is there radiological and hazardous materialwaste stored in the building/structure?
$\square$ Yes
$\square$ No
口 Unknown

IF NO, SKIP TO SECTION VII OF THIS CHECKLIST. IF 'UNKNOWN', PROVIDE THE PRELUMINARY COST ESTIMATES FOR CHARACTERIZING UNKNOWNS (In S000); THEN SKIP TO SECTION VII OF THE CHECKLUST.:

\section{$S$}

Source of Information (Include dotails.)

Not available

$\square$ Interview/personal knowledge

$\square$ Document

Walkdown 
C-17

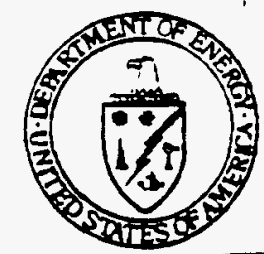

Surplus Facility Inventory and Assessment Project

Site:

RPIS Numbor:

Dato:

Rov. 11

Propared by:

V-2. Describe inventory by type DO NOT INCLUDE CLASSIFIED INFORMATION:

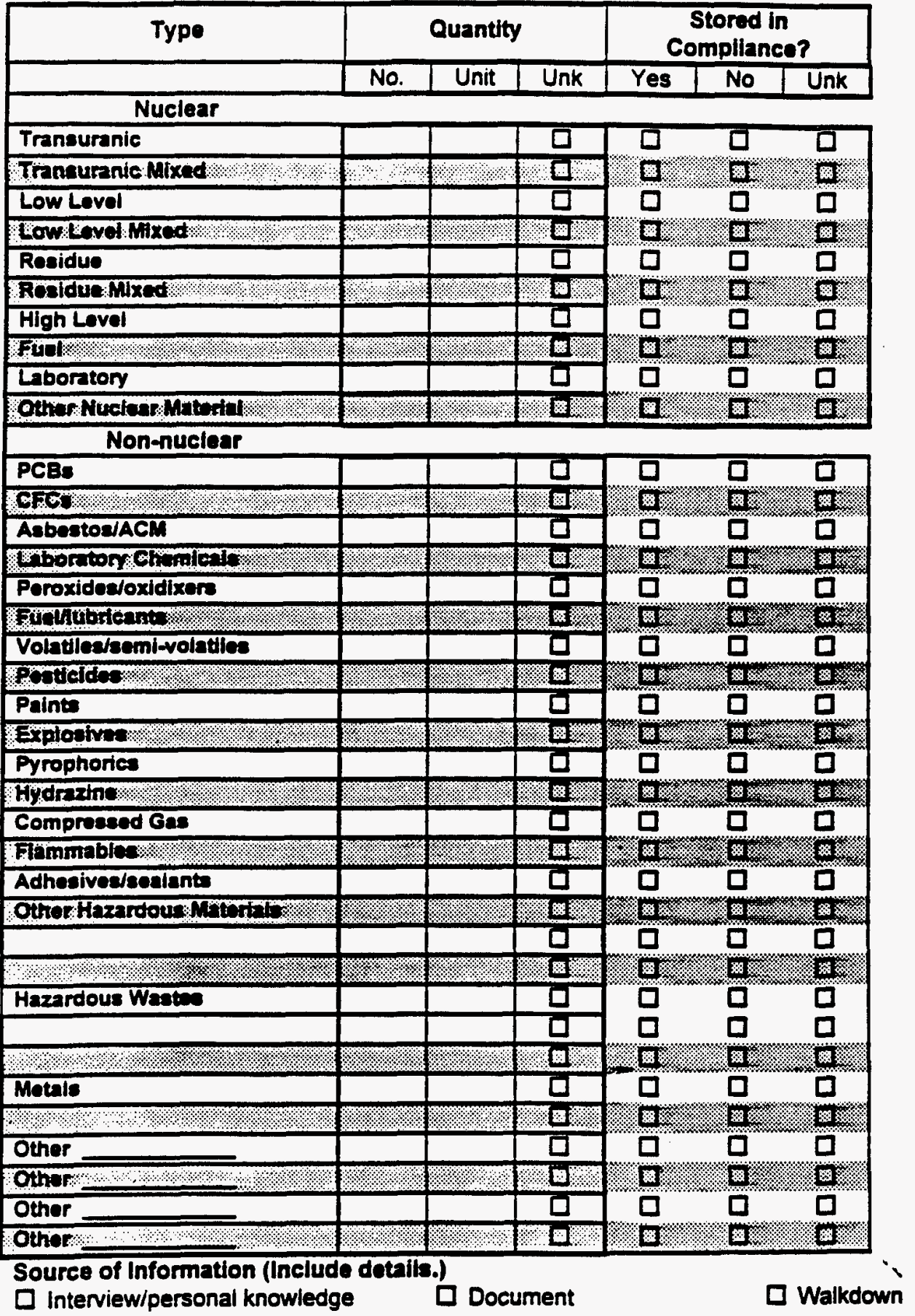




\section{C-18}

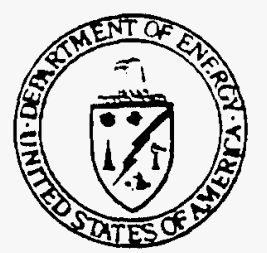

\section{Surplus Facility Inventory and Assessment Project}

Site:

RPIS Number:

Rov. 11

Pate:

Page 14

V-3. Are there plans to consolidate and/or relocate any of the waste or materials to or from this building/structure?
Yes (TO)
$\square$ Yes (From)
$\square$ No
Unknown

Source of Information (include details.)

$\square$ Interview/personal knowledge $\square$ Document $\quad \square$ Walkdown

V4. Does the material and waste inventory or storage condition present an immediate and serious problem for (describe condition in remarks).

\begin{tabular}{|c|c|c|c|c|}
\cline { 2 - 5 } \multicolumn{1}{c|}{} & Worker & Public & Environment & Building/Struct. \\
\hline Yes & $\square$ & $\square$ & $\square$ & $\square$ \\
\hline No & $\square$ & $\square$ & $\square$ & $\square$ \\
If yes, does an Action Plan exist (describe actions in remarks)? & \\
Yes & \multicolumn{4}{c}{ No }
\end{tabular}

If available, provide preliminary cost estimate for correcting all immediate and serious problems identified (\$000):

Source of Information (include dotalla.)

$\square$ Interview/personal knowledge $\square$ Document

$\square$ Walkdown 


\section{C-19}

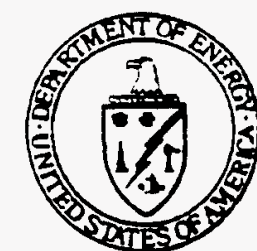

Sito:

RPIS Number:

Surplus Facility Inventory and Assessment Project

Rev. 11

Date:

Prepared by:

Page 15

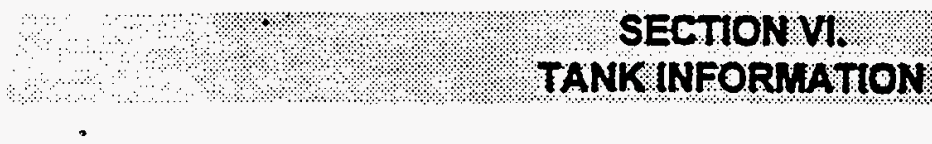

४ै। 
C-20

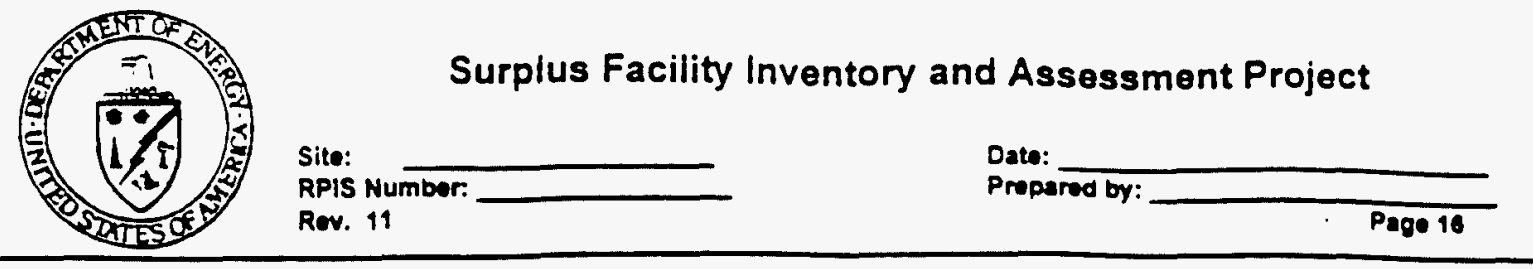

\section{SECTION VII. SAFEGUARDS AND SECURITYINFORMATION}

PURPOSE: Provide basic information on building/structure safeguarde and security.

USE: $\quad$ To determine the need for and magnitude of safeguards and security messures. DO NOT INCLUDE CLASSIFIED INFORMATION.

VII-1. Are Safeguards and Security measures in place to maintain the necessary level of protection?

$\square$ Yes $\square$ No $\square$ None Necessary

[IF RESPONSE IS 'NONE NECESSARY, EXPLAIN IN REMARKS BLOCK AND

PROCEED TO SECTION VIII OF THIS CHECKLIST.]

Remarks:

Source of Information (Include details.)

$\square$ interview/personal knowledge $\square$ Document

Walkdown

VII-2. List all security interests in the building/structure:
口 Classified documents
$\square$ Classified material
Classified computers
$\square$ Property protection
Special Nuclear Materials
$\square$ Other Nuclear Materials
$\square$ Classified equipment
Unknown
$\square$ Other -Specity:

Source of Information (Include dotails.)

$\square$ interview/personal knowledge

$\square$ Document

Walkdown

VII-3. If Special Nuclear Material is located in the building/structure, is it stored in vaults or vault-type rooms?

$\square$ Yes $\square$ No Unknown $\square$ Not Applicable

Source of Information (Inelude detalts.)

$\square$ Interview/personal knowiedge $\square$ Document $\square$ Walkdown

VII-4. Are there plans to consolidate or relocate security interests to or from this building/structure?
$\square$ Yes (To)
$\square$ Yes (From)
ㅁ No
u Unknown

Source of Information (Include datalis.)

$\square$ Interview/personal knowledge $\square$ Document

Walkdown

VII-5. Does the Safeguards and Security situation present an immediate and serious problem for (describe in remarks).

\begin{tabular}{|c|c|c|c|c|}
\cline { 2 - 5 } \multicolumn{1}{c|}{} & Worker & Public & Environment & Building/Struct. \\
\hline Yes & $\square$ & $\square$ & $\square$ & $\square$ \\
\hline No & $\square$ & $\square$ & $\square$ & $\square$
\end{tabular}

If yes, does an Action Plan exist (describe actions in remarks)? $\square$ Yes $\square$ No

If available, provide preliminary cost estimate for correcting all immediate and serious problems identified (\$000): $\square$ Not available

Source of Information (Include details.)

$\square$ Interview/personal knowledge

Document

Walkdown 


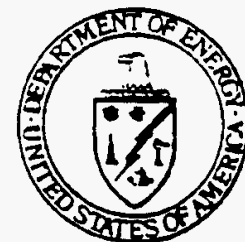

Surplus Facility Inventory and Assessment Project

Site:

RPIS Number:

Rev. 11
Date:

Propared by:

\section{SECTION VII: SYSTEM CONDITIONINFORMATION}

\section{PURPOSE: Determine the condition of systems within the building/atructure. \\ USE: To identify system doficiencios and asseas risks and hazards associated with such deficiencies.}

VIII-1. What is the condition of building systems in the building/structure? Use blank rows for other critical building systems:

\begin{tabular}{|c|c|c|c|c|c|c|c|}
\hline & & tent & Syotum stonter & Syotant & $\infty$ & 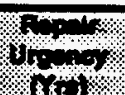 & Repons \\
\hline $\begin{array}{l}\text { Bulloing System or } \\
\text { Component }\end{array}$ & rem & no & 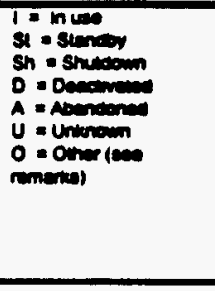 & 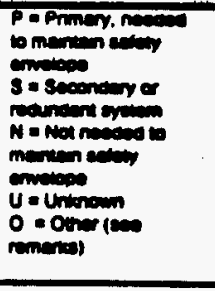 & 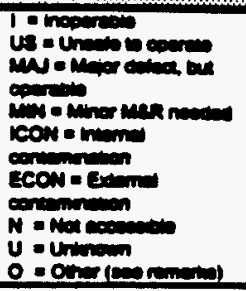 & & \\
\hline HVAC & 므 & ㅁ & & & & & \\
\hline Inert Atmosphene & 口 & $\square$ & & & & & \\
\hline Emergengy Cooling & 口 & ㅁ & & & & & \\
\hline Fire Suppression & 口 & 口 & & & & & \\
\hline Eloctrical Distribution & $\square$ & 口 & & & & & \\
\hline Emergency Power & 口 & ㅁ & & & & & \\
\hline Uninterrupted Power & 口 & 口 & & & & & \\
\hline Fire Detection/Alamm & 口 & $\square$ & & & & & \\
\hline Rad Alam & 므 & 口 & & & & & \\
\hline Evacuation Alarm & 口 & 口 & & & & & \\
\hline Leak Delection & 口 & 口 & & & & & \\
\hline Security Alamm & $\square$ & ם & & & & & \\
\hline Criticality Alam & $\square$ & 口 & & & & & \\
\hline Lighting & 무 & ㅁ & & & & & \\
\hline Plumbing & ㅁ & 므 & & & & & \\
\hline Roofing & 口 & $\square$ & & & & & \\
\hline Exterior Closure & $\square$ & ㅁ & & & & & \\
\hline Secondary Containm. & ㅁ & 므 & & & & & \\
\hline Structural & $\square$ & $\square$ & & & & & \\
\hline & $\square$ & $2 \%$ & & & & & \\
\hline & 口 & 3 & & & & & \\
\hline
\end{tabular}


C-22

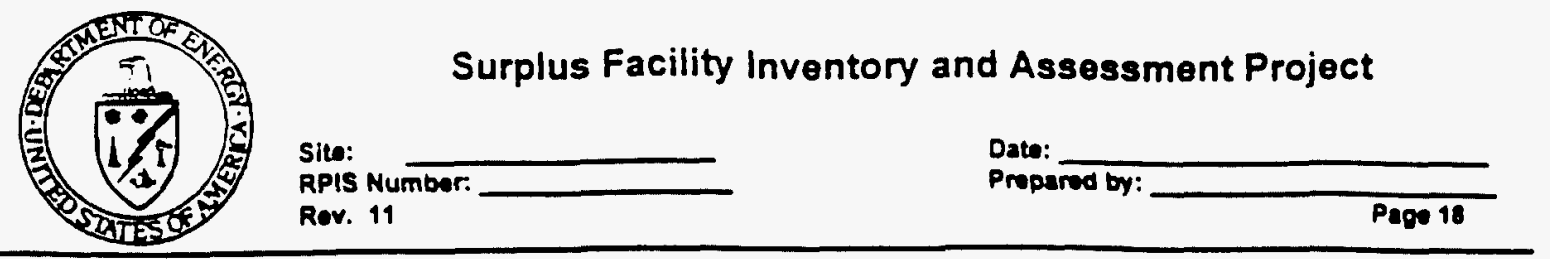

VIII-2. Does any building/structure physical condition present an immediate and serious problem for (describe condition in remarks).

\begin{tabular}{|c|c|c|c|c|}
\cline { 2 - 6 } \multicolumn{1}{c|}{} & Worker & Public & Environment & Building/Struct. \\
\hline Yes & $\square$ & $\square$ & $\square$ & $\square$ \\
\hline No & $\square$ & $\square$ & $\square$ & $\square$
\end{tabular}

If yes, does an Action Plan exist (describe actions in remarks)?

Yes $\square$ No

If available, provide preliminary cost estimate for correcting all immediate and serious problems identified

(\$000): DNot available

Source of Information (Include datalls.)

$\square$ Interview/personal knowledge $\square$ Document $\square$ Walkdown 
Sito:

RPIS Number:

Rov. 11
Dato:

Propared by:

\section{SECTIONIX.}

STANB

COMPLETE THIS SECTION FOR STAND-ALONE TANKS NOT ASSOCLATED WTH A SPECIFIC BUILDING/STRUCTURE. FOR TANKS LOCATED IN A TANK FARM, COMPLETE A SEPARATE SECTION FOR EACH TANK.

IX-1. What is the FY93 actual and unfunded direct and indirect Surveillance and Maintenance (S\&M) cost for this tank? If available, provide a cost estimate for each of the elements in the shaded blocks below. Otherwise, provide the totals for Direct and indirect costs. If S\&M cost estimates cannot be obtained on a tank level, provide S\&M cost estimates on a tank farm, specitying (in the remarks section) the group of tanks included in the total.

\begin{tabular}{|c|c|c|c|c|}
\hline & \multicolumn{2}{|c|}{ Actual } & \multicolumn{2}{|c|}{ Unfunded } \\
\hline & $\begin{array}{l}\text { Direct } \\
(\$ 000)\end{array}$ & $\begin{array}{c}\text { Indirect } \\
(\$ 000)\end{array}$ & $\begin{array}{l}\text { Direct } \\
(3000)\end{array}$ & $\begin{array}{l}\text { Indirect } \\
(\$ 000)\end{array}$ \\
\hline Surveillance & 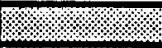 & & 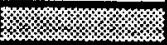 & 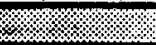 \\
\hline Safeguards and Security & & \% & 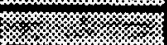 & \\
\hline Environment, Safety and Health & א. & & 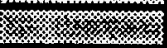 & x \\
\hline Custodial Fees & 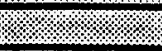 & & s. & $x$ \\
\hline Backlog of Maintenance and Repair & & 1. & 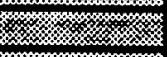 & x \\
\hline Maintenance & 1.:- & \% & 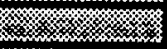 & 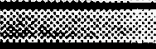 \\
\hline Emergency Preparation & (3x/ & 媇 & $\operatorname{mos}_{x}$ & mans \\
\hline Utilities & (1) & 楼 & 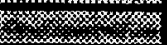 & 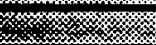 \\
\hline Leases & 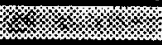 & 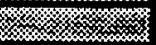 & 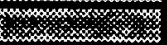 & 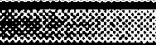 \\
\hline Property Taxes or fees & 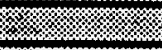 & 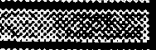 & 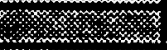 & 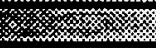 \\
\hline Other (specify) & 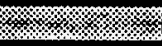 & $x$ & 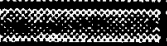 & $x$ \\
\hline Other (specify) & & 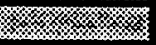 & 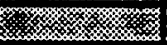 & / \\
\hline Other (specify) & & 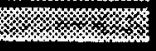 & 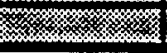 & \\
\hline
\end{tabular}

\begin{tabular}{|l|l|l|l|l|}
\hline Direct (\$000): & Actual: & & Unfunded: & \\
\hline Indirect (\$000): & Actual: & & Unfunded: & \\
\hline
\end{tabular}

What is the basis for this S\&M cost estimate?
口 Actual
口 Percent of replacement value
Q Percent of operating budget
O Other - Specify:

How much of this cost is for the Backlog of Maintenance and Repair (BMR) (in S000)?

$\$$

Source of Information (include datails.)

$\square$ Interview/personal knowledge

Document

Walkdown 


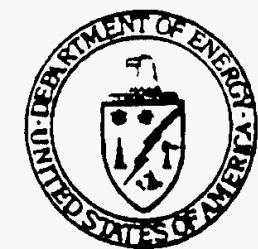

Sito:

RPIS Number:

Rev. 11

\section{Surplus Facility Inventory and Assessment Project}

Date:

Propared by:

IX-2. Assuming the tank will cease mission-related operations within the next five years, are there additional annual and one-time activities (not addressed in the preceding two questions) that would be necessary to prevent the tank from further deterioration and to maintain it in an environmentally acceptable manner? If yes. please provide cost (do not include one-time costs associated with characterization requirements andor comection of immediate and senious Yes problems identified elsewhere in this checklist):

Additional annual cost: $\mathbf{s}$ Additional one-time cost $s$

Brieffy describe one-time cost activities:

Source of Information (Include dotails.)

$\square$ Interview/personal knowledge

$\square$ Document

Walkdown

IX-3. Complete the table below for the tank, identifying the RPIS number, if the RPIS number (or other identification).

\begin{tabular}{|c|c|}
\hline \multirow{2}{*}{\multicolumn{2}{|c|}{ Tank Type $A=$ Above Ground $B=$ Under Ground }} \\
\hline & \\
\hline \multicolumn{2}{|l|}{ Capacity (Gab) } \\
\hline \multicolumn{2}{|c|}{ Undorground Plpes $(Y=Y e s ;, N=$ No;,$U=$ Unknown $)$} \\
\hline \multicolumn{2}{|c|}{ Operational $(Y, N, U)$} \\
\hline \multicolumn{2}{|c|}{ Empty $(Y, N, U)$} \\
\hline \multicolumn{2}{|c|}{ 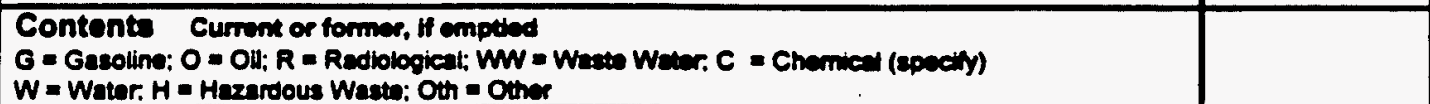 } \\
\hline \multicolumn{2}{|c|}{ PrecisionlLeak Tested? $(Y, N, U)$} \\
\hline \multicolumn{2}{|l|}{ Leaking or Leaked in Past? $(Y, N, U)$} \\
\hline \multicolumn{2}{|c|}{ Lining? (S = Singie enell: D - Double enen) } \\
\hline \multicolumn{2}{|c|}{ 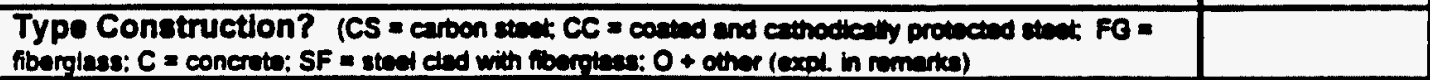 } \\
\hline \multicolumn{2}{|c|}{ Signs of Overflow? $(Y, N)$} \\
\hline \multicolumn{2}{|l|}{ Soll Contamination $(Y, N, U)$} \\
\hline \multicolumn{2}{|l|}{ Ground wator Contamination $(Y N, U)$} \\
\hline \multicolumn{2}{|l|}{ RCRA Regulated? (Y, N. U) } \\
\hline Documented Clean Closure (Y, N, U) & \\
\hline
\end{tabular}

Source of Information (include datails.)

$\square$ Interview/personal knowiedge

$\square$ Document

Walkdown 


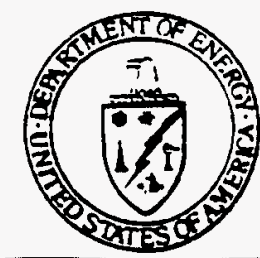

Sito:

RPIS Number:

Rov. 11

\section{Surplus Facility Inventory and Assessment Project}

Dato:

Propared by:

Page 21

IX-4. Are Safeguards and Security measures in place to maintain the necessary level of protection?

$\square$ Yes $\square$ No $\square$ None Necessary

Remarks:

Source of Information (Include details.)

$\square$ Interview/personal knowledge $\square$ Document

Walkdown

IX-5. Is there current RCRAVCERCLA activity ongoing at this tank or tank farm?

$\square$ Yes (Describe in Romarks) $\square$ No

Source of Information (Include details.)

$\square$ interview/personal knowledge

$\square$ Document

Walkdown

IX-6. Does this tank present an immediate and serious problem for (describe condition in remarks).

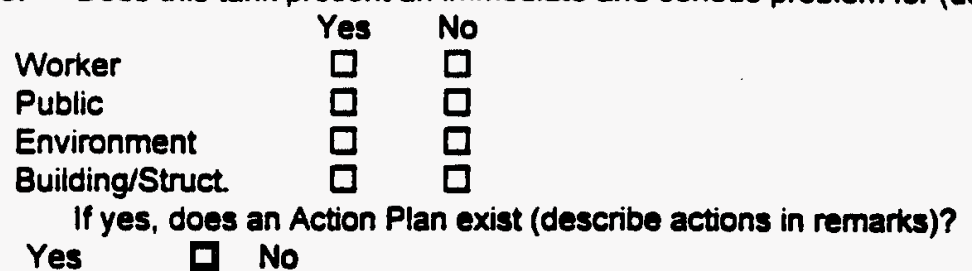

If available, provide preliminary cost estimate for correcting all immediate and serious problems identified (\$000): Not Available

Source of Information (Include datails.)
$\square$ Interview/personal knowledge
$\square$ Document
Walkdown

IX-7. What is the most significant regulatory compliance status of this tank?

口 Major non-compliance with Federal, State, Local laws

$\square$ Major non-compliance with interagency agreements

口 Marginal or isolated non-compliance with law

Marginal or isolated non-compliance with interagency agreements

$\square$ Deviation from documented but not law-based requirements (e.g., DOE Orders, Best Management Practices)

None of the above

Briefly describe noted non-compliance:

\section{Source of Information (Include details.)}
$\square$ Interview/personal knowledge
$\square$ Document
$\square$ Walkdown 


\section{C-26}

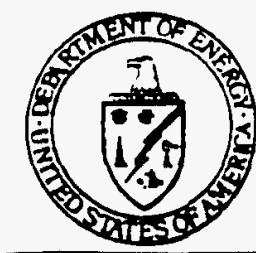

Surplus Facility Inventory and Assessment Project

Site:

RPIS Number:

Rov. 10
Date:

Propared by:

Remarts form Page _ of _

Use this form for remarks:

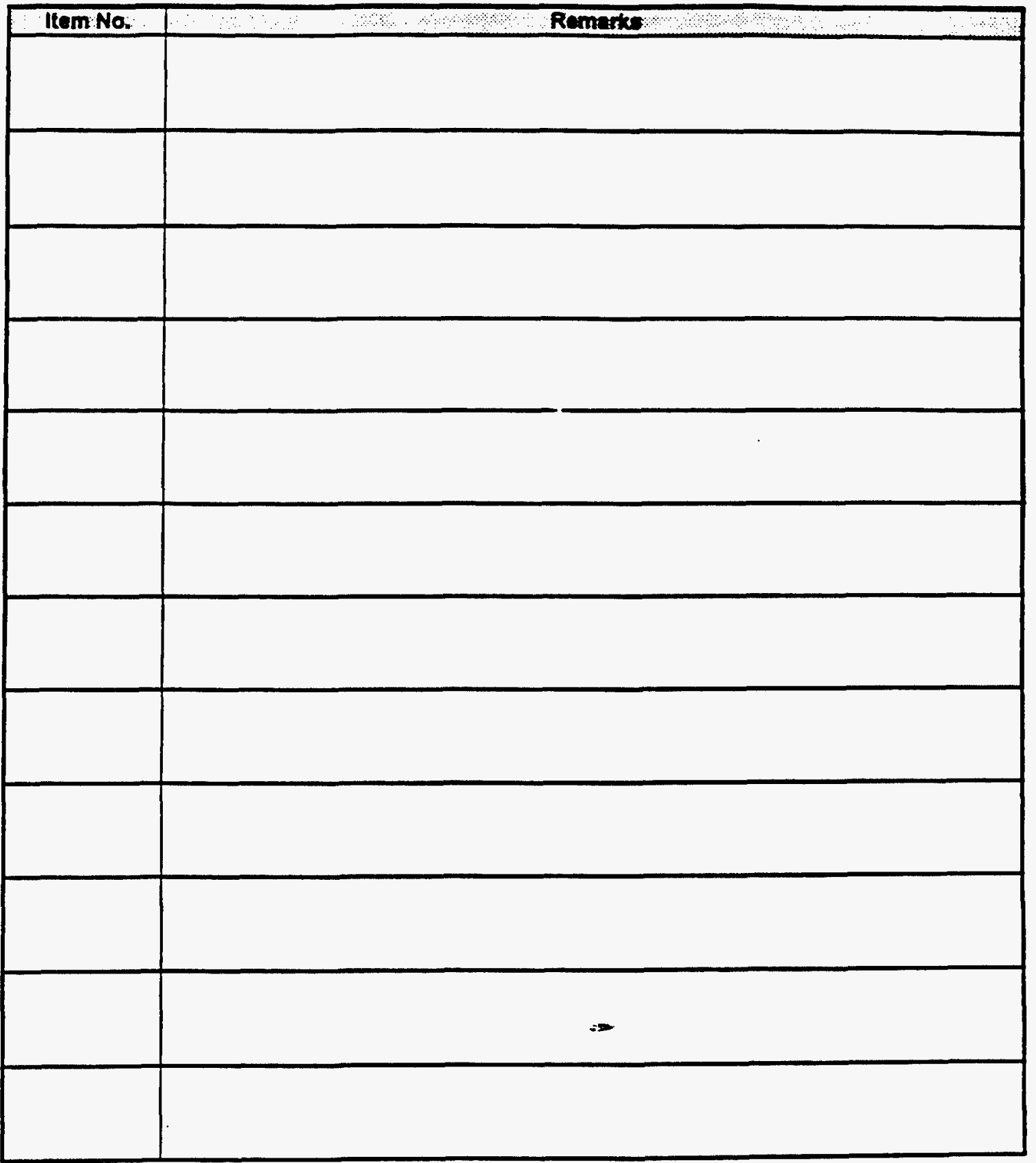




\title{
DISTRIBUTION
}

\author{
1. L. V. Asplund \\ 2. H. L. Boston \\ 3. J. T. Bradbury \\ 4. K. W. Cook \\ 5. C. E. Daughety \\ 6. M. F. P. Delozier \\ 7. L. D. Hyde \\ 8. J. R. Lyons \\ 9. A. R. Medley \\ 10. T. W. Morris \\ 11-12. P. T. Owen \\ 13. D. C. White \\ 14. ORNL Laboratory Records \\ 15. Central Research Library \\ 16. ER Document Management Center-RC
}




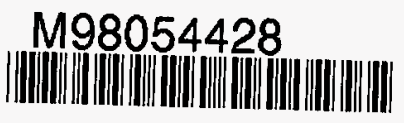

Report Number (14) ORNL/ER--296

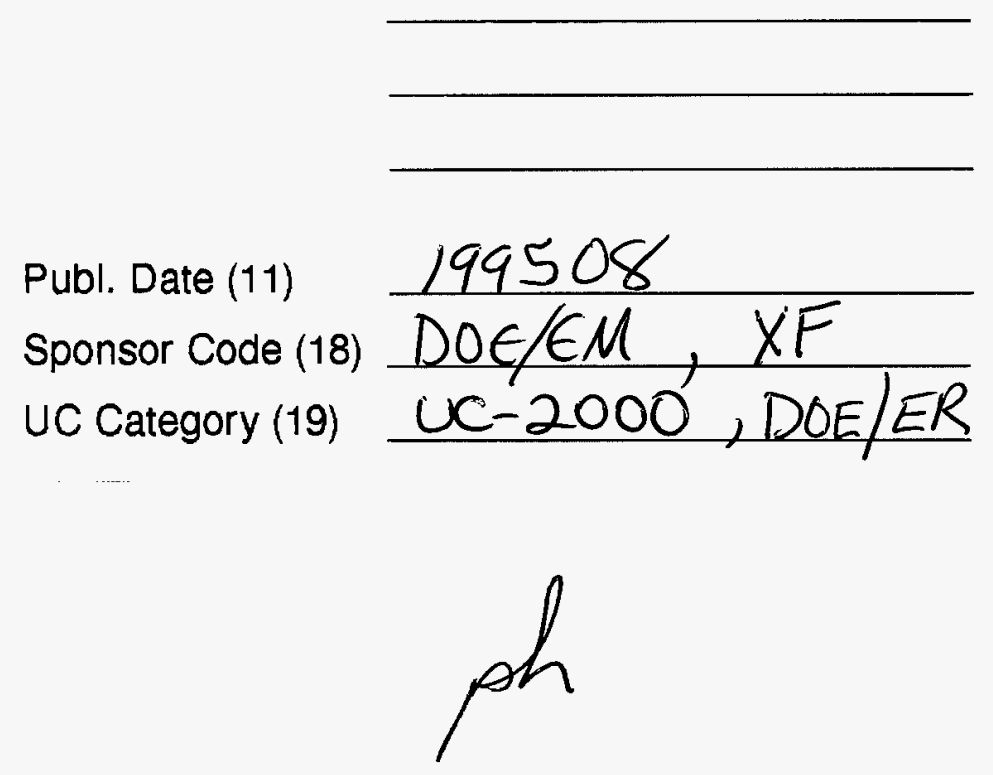

\section{3}

